\title{
CHERNELHÁZI CHERNEL ISTVÁN MUNKÁINAK JEGYZÉKE
}

\author{
Összeállította \\ Faragó Sándor \\ Soproni Egyetem, Vadgazdálkodási és Gerinces Állattani Intézet \\ University of Sopron, Institute of Wildlife Management and Vertebrate Zoology \\ H-9400 Sopron, Bajcsy-Zs u. 4., Hungary
}

\begin{abstract}
FARAGÓ S. (2019): BIBLIOGRAPHY OF ISTVÁN CHERNEL. Hungarian Small Game Bulletin 14: 19-46. http://dx.doi.org/10.17243/mavk.2019.019

So far nobody has made a chronological elaboration on ISTVÁN CHERNEL's work of scientific literature. Making up the lack of this, the author is showing the 361 theses, which might be attributed to CHERNEL. This also means the revision of an earlier work. The complete life-work is only available at the Institute of Wildlife Management and Vertebrate Zoology at the University of Sopron.
\end{abstract}

KULCSZAVAK: CHERNEL ISTVÁN, bibliográfia KEY WORDS: ISTVÁN CHERNEL, bibliography

\section{BEVEZETÉS}

Chernelházi CHERNEL ISTVÁN irodalmi munkásságával hosszú ornitológusi pályafutásom során folyamatosan szembesültem, de különösen intenzívvé vált a vele való foglalkozás akkor, amikor születésének 150. évfordulójára készülödtünk. A Rá való emlékezések, konferencia a Magyar Tudományos Akadémián (2015. június 4.) és szülővárosában Kőszegen (2015. november 30.), szoborállítás Agárdon, a szabadparti sétányon, a Velencei-tónál (2015. május 31.), emléktábla avatás Sopronban egykori gimnáziuma (2015. október 22.) (FARAGÓ, 2016) és Badacsonyi nyaralója (2017. október 29.) falán, megemlékezések folyóiratokban (Nimród Vadászújság, Életünk, Aquila) (FARAGó \& MAJTHÉNYI 2015a, 2015b, FARAGÓ 2017), mind szükségessé tették az írott életmü áttekintését is. Megtetőzte mindezt az a kétkötetes monográfia, amely 10 év munkája nyomán került ki a nyomdából „Lélekkel teljesitett hivatás” címmel (FARAGÓ 2015).

E munkálatok során nagy segítségemre volt az a bibliográfia, amit VÉRTESI PÉTERNÉ (SRAGNER MÁRTA) állított össze, s amely 1981-ben Szombathelyen a Berzsenyi Dániel Megyei Könyvtár adott ki (VÉRTESI 1981), s amely 2014 óta digitálisan is elérhető az OSZK honlapján (SRAGNER 2004).

Az életrajz írásakor szembesültem azzal a ténnyel, hogy a bibliográfia nem hagyományos módon, azaz kronologikus sorrendben adja meg a közlemények listáját, hanem tematikus csoportosításban. E csoportok az alábbiak: [1] Madártani, madárvédelmi írásai, [2] Madártani viták, [3] Vadászati szakcikkei, [4] A lábszánkózásról, síelésről szóló cikkei, végül [5] Egyéb írásai. Ez a felhasználóbarát megközelítés lehetővé teszi CHERNEL egyes tevékenységi körei iránti érdeklődők számára a gyors forráskeresést, ugyanakkor a témák közötti átfedések bizonytalanná és nem mindig valóssá teszik a besorolást (pl. átfedés a vadászati és madártani cikkek témái között, a nyelvészeti cikkek tulajdonképpen madártani alapúak stb.).

Ugyanakkor - bár kétséget kizáróan értékes - az egyes, elsősorban könyvek ismertetését bemutató, méltató cikkek hivatkozásszerü megnevezése, sorszámozása, mintegy CHERNEL szerzeményként való feltüntetése zavaró és könyvészetileg sem feltétlenül helytálló. 
A VÉRTESI (1981)-féle bibliográfia erényei közt tarthatjuk számon, hogy a CHERNEL korára jellemző tudományos vitákat úgy ismerteti a megérthetőség okán, hogy nem csak egyoldalúan CHERNEL írásait mutatja be, hanem vagy az azt kiváltó írást, vagy CHERNEL írásaira adott válaszokat is. Ezt magunk is megtettük a bibliográfia végén. Eltérünk az ugyancsak zavaró, mert nem feltétlenül ellenőrizhető módon ua. jelzéssel bemutatott párhuzamos közlések ismertetésében.

Az erényei miatt bizton mondhatjuk, hogy a jövőben is alkalmazhatók e bibliográfiák, ugyanakkor hiányát éreztük egy kronologikus bibliográfia összeállításának, amit ezennel megteszünk, hasonlóképpen, mint azt tette a kor elvárásainak megfelelöen SCHERMANN (1922) CHERNEL ISTVÁN halálakor, az emlékének szentelt Aquila kötetben.

Ugyanakkor azzal a jelenséggel is szembesültünk, hogy számtalan könyvtárban találtuk meg határainkon belül és túl (még az USA-ban is) az egyes cikkeket, azaz CHERNEL ISTVÁN irodalmi hagyatéka nincs összegyüjtve! Ezt e bibliográfia összeállítása során megtettük, így a Soproni Egyetem Vadgazdálkodási és Gerinces Allattani Intézetében a teljes irodalmi hagyaték, a „Chernel összes" rendelkezésre áll. Digitalizálása folyamatban van, aminek elkészültét követően mindez elérhető lesz a szakközönség számára is.

\section{ANYAG ÉS MÓDSZER}

Az említett bibliográfiák információit felhasználva, összegyüjtve a teljes CHERNEL életmüvet, felülvizsgáltuk azok minden tételét, ugyanis SCHERMANN (1922) valószínüleg CHERNEL ISTVÁN autobibliográfiáját vette alapul, amelyben olyan tétel is szerepelt, amelyet CHERNEL kéziratként nyilvántartott és elküldött megjelentetésre. Így fordulhat elő, hogy szerepelnek olyan közlések, amik nem jelentek meg, illetve amelyek magyarul vannak a SCHERMANN-féle bibliográfiában, de valamely német nyelvü kőszegi, vagy soproni napilapban jelentek meg.

Arra is akad példa, hogy CHERNEL írásként szerepeltet a bibliográfiában tételeket, amelyeket a valóságban az újságíró/szerkesztő mintegy interjúként már saját neve alatt jelentetett meg, igaz CHERNEL szájába adva mindazt, amit CHERNEL cikk gyanánt küldött. Ezeket korrigáltuk []-jelben megadva a „közös” cikk tényét (lásd 281. és 282. tétel).

Külön sorszámmal jelöltük - eltérően VÉRTESI (1981), illetve SRAGNER (2004) bibliográfiáitól -, hiszen külön tétel és hivatkozási egység, ha - a korszak elfogadott módszerének megfelelően - ugyanazt az írást több folyóiratban is publikálta CHERNEL. Ennek a többirányú publikációnak az oka az volt, hogy az egyes folyóiratok, periodikák más-más társadalmi rétegeket, célközönséget szólítottak meg, amelyek mindegyikéhez el akarta juttatni CHERNEL az új tudományterület, az ornitológia eredményeit, illetve az ugyancsak akkor szárnyát bontogató madárvédelem üzeneteit.

Az újságokban megjelent cikkek sokszor több folytatásban kerültek kiadásra, ezeket is külön sorszámmal és hivatkozási tétellel, illetve az összetartozást a cím végén []-jellel és sorszámmal adjuk meg.

CHERNEL ISTVÁN ornitológus, zoológus volt. Jelen bibliográfia - eltérően VÉRTESI (1981), illetve SRAGNER (2004)-féle kiadástól - a zoológiában szokásos, jelen korban is alkalmazott hivatkozás szerint adja meg a szerző, a megjelenés éve, cím és forráshelyeket. Vonatkozik ez a régi újságcikkekre is, amelyeknél SCHERMANN (1922) még megadta az évfolyamot és a lapszámot, VÉRTESI (1981) és SRAGNER (2004) pedig már nem [utóbbiakban többnyire év és lapszám, vagy év és dátum szerepel, az évfolyam mindig, a lapszám olykorolykor hiányzik: pl. Vadász-Lap 1884. 7. sz. (évfolyam hiányzik), illetve Köszeg és Vidéke 1886. máj.16. (évfolyam és lapszám hiányzik)]. 
Említett bibliográfiákkal szemben viszont nem szerepeltettük a listában a cikkekre érkezett méltatásokat, ismertetéseket.

Mi is megadjuk - a bibliográfia végén - a többszöri közlésü publikációk összefüggéseit, illetve a vitairatok „társ cikkeit”, hogy értelmezhetők és visszakereshetők legyenek azok is.

\section{BIBLIOGRÁFIA Kronologikus sorrendben}

1880

1. Chernel I. (1880): Nyári vadászatok sikeréről - Köszegről... Vadász-Lap 1 (32): 358.

1881

2. CHERnEl I. (1881): Köszeg és vidéke (Hazai vadászterületeink IX.). Vadász-Lap 2 (22): 177-178.

3. CHERNEL I. (1881): Kőszeg és vidéke. Vasmegyei Lapok 15 (46): 1-2.

4. CHERnEl I. (1881): Reggeli séta a szabadban. Köszeg és Vidéke 1 (1): 1-2.

5. CHERnEl I. (1881): Az utolsó virág. Köszeg és Vidéke 1 (15): 1-2.

\section{2}

6. CHERnEL I. (1882): Néhány nap Zalamegyében [1]. Köszeg és Vidéke 2 (21): 1-2.

7. CHERnel I. (1882): Néhány nap Zalamegyében [2]. Köszeg és Vidéke 2 (22): 1-2.

8. CHERnel I. (1882): Néhány nap Zalamegyében [3]. Köszeg és Vidéke 2 (23): 1-2.

9. CHERnel I. (1882): Néhány nap Zalamegyében [4]. Köszeg és Vidéke 2 (24): 1-2.

10. Chernel I. (1882): Néhány nap Zalamegyében [5]. Köszeg és Vidéke 2 (25): 1-2.

11. CHERNEL I. (1882): Karácsonyéji népmonda. Köszeg és Vidéke 2 (52): 1-2.

12. Chernel I. (1882): Egy korcs, hamvas varjú... Vadász-Lap 3 (5): 85.

13. CHERnEl I. (1982): Itt vannak ök! Vadász-Lap 3 (28): 346-347.

\section{3}

14. Chernel I. (1883): Hattyuk a Fertő taván. Vadász-Lap 4 (2): 26.

15. Chernel I. (1983): Zergét lőttek Vasmegyében. Vadász-Lap 4 (2): 26.

16. CHERnEl I. (1883): Szerény megjegyzések. Vasmegye vadászterületeinek ismertetéséhez. Vadász-Lap 4 (7): 82-83.

17. CHERnEl I. (1883): Abnormalis csőr-képződés egy fogoly-madárnál. Vadász-Lap 4 (24): 295. A cikkhez ábra Vadász-Lap 4 (26): 323.

18. Chernel I. (1983): Csabrendek vidéke Zalamegyében. Vadász-Lap 4 (25): 303-304.

19. CheRnEl I. (1883): November havi vadászatok Vasmegyében. Vadász-Lap 4 (33): 400401.

20. CHERNEL I. (1883): Vidékünk vadászatai. Vadász-Lap 4 (35): 427.

21. CHERnEL I. (1883): A fenyves rigó vadászata. Szemle 1 (1): 7-8.

22. Chernel I. (1883): Utiképek Stayerországból [1]. Köszeg és Vidéke 3 (2): 1-3.

23. CHERnEl I. (1883): Utiképek Stayerországból [2]. Köszeg és Vidéke 3 (3): 1-3.

24. ChERnel I. (1883): Utiképek Stayerországból [3]. Köszeg és Vidéke 3 (4): 1-3.

25. Chernel I. (1883): Utiképek Stayerországból [4]. Köszeg és Vidéke 3 (5): 1-3.

26. CHERnEl I. (1883): Vidékünk hasznos és káros madarai. Köszeg és Vidéke 3 (25): 1-2. 


\section{4}

27. Chernel I. (1884): Vidékünk vadászatai. Vadász-Lap 5 (2): 17.

28. CHERNEL I. (1884): Az első szalonkák! Vadász-Lap 5 (7): 91.

29. CHERnel I. (1884): A hosszucsőrüek. Vadász-Lap 5 (31): 419-420.

30. CHERnEl I. (1884): Pozsonymegyei vadászatok. Vadász-Lap 5 (35): 486.

\section{5}

31. Chernel I. (1885): A vadászatok Vasmegyében. Vadász-Lap 6 (2): 17-18.

32. CHERnEl I. (1885): A „Kis-Kárpátokból”. Vadász-Lap 6 (6): 77-80.

33. CHERNEL I. (1885): Visszapillantás tavaszi szalonka-évadunkra. Vadász-Lap 6 (12): 160 161.

34. Chernel I. (1885): Az erdei szalonka költéséhez. Vadász-Lap 6 (18): 237-238.

35. CHERNEL I. (1885): Egy hét a fogoly-vadászatok Eldorádojában. Vadász-Lap 6 (24): 319320.

36. CHERnEl I. (1885): Az őszi szalonka-idényről. Vadász-Lap 6 (31): 414-415.

37. CHERNEL I. [QUERCUS] (1885): Köszeg vidékén előforduló emlősök és madarak. Köszeg és Vidéke 5 (5): 1-3.

38. CHERNEL I. (1885): Öngyilkosság és halálos ítélet az állat illetőleg a madárvilágból. I. Köszeg és Vidéke 5 (20): 1-3.

39. CHERNEL I. (1885): Öngyilkosság és halálos ítélet az állat-, illetőleg a madárvilágból. II. Köszeg és Vidéke 5 (21): 1-2.

40. CHERNEL I. (1885): Öngyilkosság és halálos ítélet az állat-, illetőleg, a madárvilágban I. Hon 1 (8): 2. [A II. rész nem jelent meg, mert a lap megszünt]

41. CHERnel I. (1885): Párbaj a madárvilágban. Szemle 2 (12): 9-12.

42. Chernel I. (1885): Emlékezés Kemény Hugóra. Sopron 15 (17): 1.

\section{6}

43. Chernel I. (1886): Pozsonyvidéki téli vadászatok. Vadász-Lap 7 (3): 50-51.

44. CHERnEl I. (1886): Szalonkáink tavaszi vonulása. Vadász-Lap 7 (13): 185-186.

45. CHERnEL I. (1886): Hódak a Csallóközben. Vadász-Lap 7 (18): 257-258.

46. CHERnel I. (1886): Kacsavadászat a szent-györgyi „Soór”-ban. Vadász-Lap 7 (23): 315316.

47. ChERnEl I. (1886): Vadászatok. Kőszeg. Vadász-Lap 7 (23): 316.

48. CHeRnel I. (1886): Fogoly-vadászatok Sopron- és Vasmegyében. Vadász-Lap 7 (26): 353-354.

49. CHERNEL I. (1886): A fajdok elterjedése a Dunántúl nyugoti hegylánczaiban. Vadász-Lap 7 (26): 355-356.

50. CHERNEL I. (1886): Madártani megfigyelések. [1]. Köszeg és Vidéke 6 (48): 1-2.

51. CHeRnel I. (1886): Madártani megfigyelések. [2]. Köszeg és Vidéke 6 (49): 1-2.

52. Chernel I. (1886): Madaraink vándorlása [1]. Hasznos Mulattató 14 (8): 249-251.

53. Chernel I. (1886): Madaraink vándorlása [2]. Hasznos Mulattató 14 (9): 283-284.

54. CHERNEL I. (1886): A bécsi ornithologiai kiállítás. Köszeg és Vidéke 6 (20): 1-3.

55. CHERNEL I. (1886): A madarak életkora [1]. Köszeg és Vidéke 6 (25): 1-2.

56. Chernel I. (1886): A madarak életkora [2]. Köszeg és Vidéke 6 (26): 1-2.

57. Chernel I. (1886): A madarak életkora. Pozsonyvidéki Lapok 14 (100): 2-3.

58. TsChusi, V. \& CHERnEl I. (1886): Die ornithologische Literatur Österreich-Ungarns 1886. Zeitschrift für die gesammte Ornithologie 3: 271-282. 


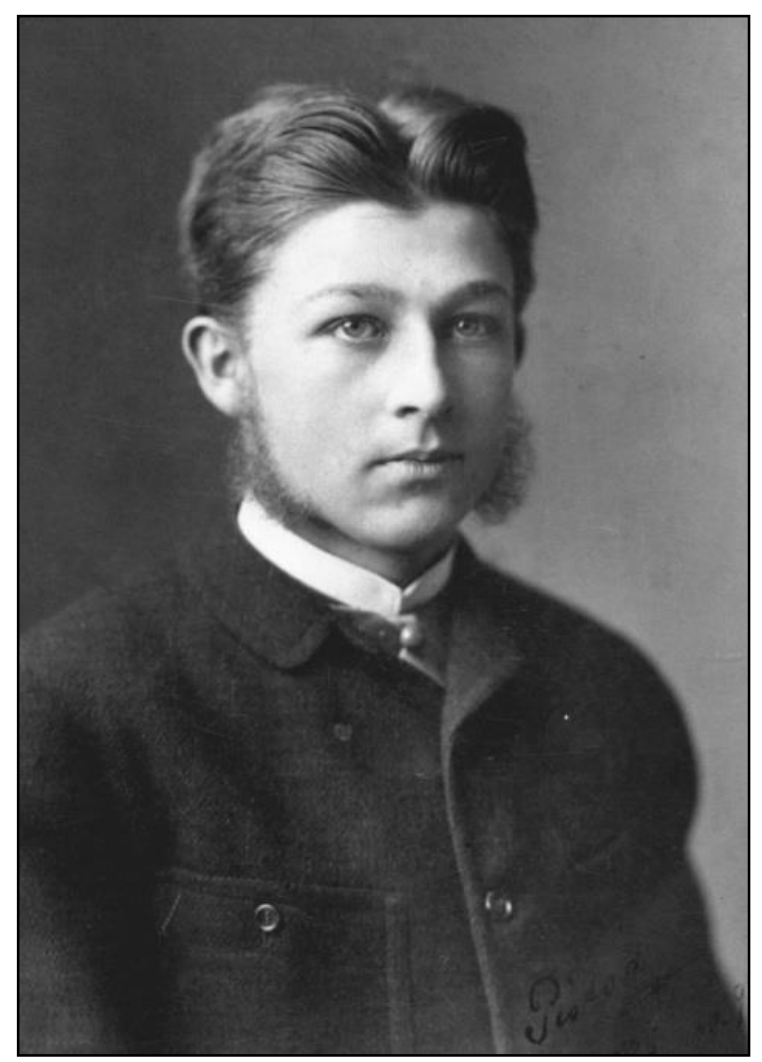

\section{1. ábra: Az ifjú CHERnEL IsTVÁN (1885. november 9 - 20 évesen)}

(Savaria Múzeum Természettudományi Osztály, Fotótár, KT 204)

Figure 1: The young István Chernel (9th November 1885 - 20 Year old)

1887

59. CHERnEl I. (1887): Torzcsőrü madarak. Vadász-Lap 8 (5): 57-59.

60. CHERNEL I. (1887): Örvös ludak Érsek-Ujvár vidékén. Vadász-Lap 8 (10): 126.

61. Chernel I. (1887): Adatok Vas-, Sopron-, Pozsony- és Fehérmegye madárfaunájához. Vadász-Lap 8 (14): 175-178.

62. Chernel I. (1887): Madártani megfigyelések Pozsony vidékén 1885-ben. A Pozsonyi Természettudományi és Orvosi Egylet Közleményei 1884-1886, Pressburg. pp.41-65.

63. CHERNEL I. (1887): Madártani megfigyelések Pozsony vidékén 1885-ben. Vadász-Lap 8 (17): 219-220.

64. Chernel I. (1887): A velenczei tó-vidék életéből. Vadász-Lap 8 (29): 374-377.

65. CHERnEL I. (1887): Kérelem, a havasi szajkó vándorlásának megfigyelése ügyében. Vadász-Lap 8 (29): 391.

66. CHERnEl I. (1887): Adataink a bölény, a kőszáli kecske és a hód egykori elterjedéséröl hazánkban. Vadász-Lap 8 (35): 459-461.

67. Chernel I. (1887): A honi madártan történetéből. I. - A madártan fejődése a XVIII. század végéig. Vadász-Lap 8 (36): 477-478.

68. Chernel I. (1887): Einige Beobachtungen über den Zwergfliegenfänger (Muscicapa parva L.). Mittheilungen des Ornithologischen Vereins in Wien 11: 20-21.

69. Chernel I. (1887): Bernicla torquata, Bechst. bei Neuhäusel in Ungarn erlegt. Mittheilungen des Ornithologischen Vereins in Wien 11: 55.

70. CHERNEL I. (1887): Sammlung von Vögeln, Nestern und Eiern, gelegentlich eines mehrwöchentlichen Aufenthaltes behufs ornithologischer Beobachtungen und 
Forschungen beim Velenczeersee (Weissenburger Com.) in Ungarn. Mittheilungen des Ornithologischen Vereins in Wien 11: 106-107.

71. ChERnEL I. (1887): A honi madártan történetéből. A madártan fejödése a XVIII-ik század végéig. Természettudományi Közlöny 19 (218): 415-418.

72. CHERnEl I. (1887): A honi madártan történetéből. II. E század elejétől a Kir. Magy. Természettudományi Társulat megalapításáig. Természettudományi Közlöny 19 (219): 456-460.

73. CHERNEL I. (1887): A honi madártan történetéből [1]. Köszeg és Vidéke 7 (1): 1-2.

74. ChERnel I. (1887): A honi madártan történetéből [2]. Köszeg és Vidéke 7 (2): 1-2.

\section{8}

75. Chernel I. (1888): A honi madártan történetéből. III. A madártan kifejlődése a Kir. Magy. Természettudományi Társulat alapításától napjainkig, azaz 1841-től 1888-ig. Természettudományi Közlöny 20 (221): 55-62.

76. Chernel I. (1888): A velenczei tó-vidék életéböl. Vadász-és Verseny-Lap 32 (2): 29-31.

77. Chernel I. (1888): A honi madártan történetéböl. II. E század elejétől a Kir. Magy. Természettudományi Társulat megalapításáig. Vadász-Lap 9 (1): 4-6.

78. Chernel I. (1888): A honi madártan történetéböl. III. A madártan kifejlödése a Kir. Magy. Természettudományi Társulat megalapításától napjainkig, azaz 1841-től 1888-ig Vadász-Lap 9 (9): 115-116.

79. Chernel I. (1888): A honi madártan történetéböl. III [2]: A madártan kifejlödése a Kir. Magy. Természettudományi Társulat megalapításától napjainkig, azaz 1841-től 1888-ig. Vadász-Lap 9 (10): 126-128.

80. CHERnEl I. (1888): A fajdfélék hybridjeiről. - A vadászati terminologia és müszótár ügyében. Vadász-Lap 9 (13): 165-166.

81. CHERNEL I. (1888): Kérelem a pusztai talpas tyuk (Syrrhaptes paradoxus Pall.) vándorlása alkalmából. Vadász-Lap 9 (23): 299.

82. ChERnEl I. (1888): A pusztai talpas-tyuk ezidei megjelenése hazánkban. Vadász-Lap 9 (36): 473-474.

83. CHERnEl I. (1888): A Magyarországban előforduló madarak névjegyzéke. Vadászok Zsebnaptára 2: 57-79.

84. CHERnEl I. (1888): Adatok honi madaraink népies elnevezéseihez. Természettudományi Közlöny 20 (228): 303-309.

85. Chernel I. (1888): Bibliographia Ornithologica Hungarica. Magyar Könyvszemle 13: 951.

86. Chernel I. (1888): Die Erlegung eines Phalaropus hyperboreus Bp. am Velenczeer See. Zeitschrift für die gesammte Ornithologie 4 (1-2): 188-190.

87. CHERnel I. (1888): Calamodyta melanopogon Bp. Brutvogel im Moraste und in den Röhrichten von Dinnyés in der Umgebung von Velenczeer See. Zeitschrift für die gesammte Ornithologie 4 (1-2): 191-192.

88. Chernel I. (1888): Xema minutum Pall. am Velenczeer See (Stuhlweissenburger Comitat) in Ungarn erlegt. Zeitschrift für die gesammte Ornithologie 4 (3-4): 435-437.

89. CHERnEl I. (1888): Seltene Durchzügler und Wintergäste in Ungarn. Mittheilungen des Ornithologischen Vereins in Wien 12: 8-9.

90. ChERnEl I. (1888): Zum heurigen Erscheinen der Steppenhühner (Syrrhaptes paradoxus, Pall.) in Ungarn. Mittheilungen des Ornithologischen Vereins in Wien 12: 157-158.

91. Chernel I. (1888): A pusztai talpas-tyúk ez idei megjelenése hazánkban. Természettudományi Közlöny 20 (232): 449-457.

92. CHERNEL I. (1888): Tájszók - Fehérmegyeiek. Magyar Nyelvőr 17 (9): 430-431. 
93. ChERnEl I. (1888): Madártoll az ember háztartásában [1]. Sopron 18 (21): 2-3. 94. CHERnEl I. (1888): Madártoll az ember háztartásában [2]. Sopron 18 (22): 1-2. 95. CHERnEl I. (1888): Madártoll az ember háztartásában [3]. Sopron 18 (23): 1-3. 96. CHERnEl I. (1888): Madártoll az ember háztartásában [4]. Sopron 18 (24): 1-2.
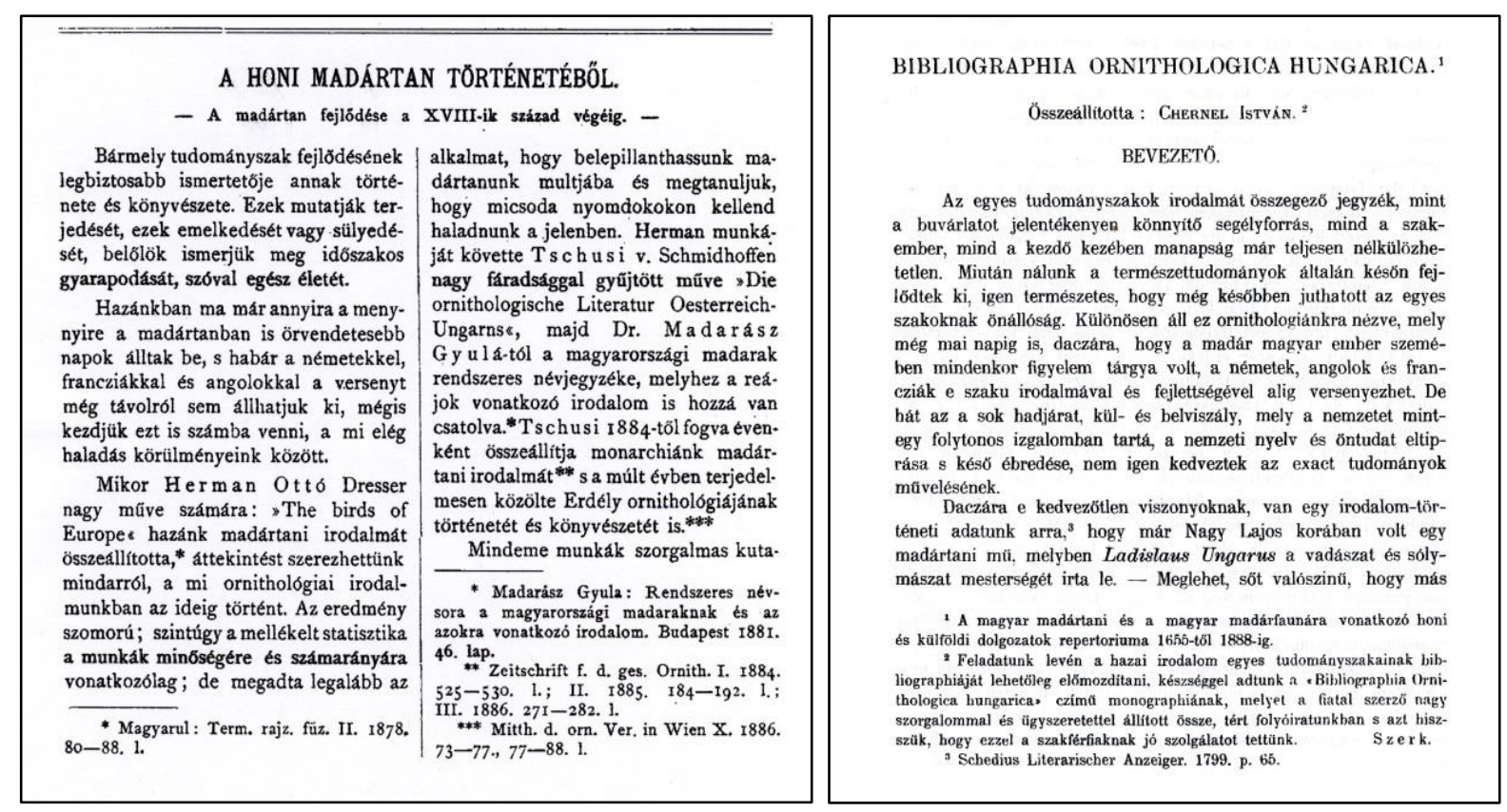

\section{2. ábra: CHERNEL ISTVÁN első átfogó tanulmányai: $A$ honi madártan történetéből és a Bibliographia Ornithologica Hungarica}

Figure 2: The first comprehensive studies of ISTVÁN CHERNEL: From the history of Hungarian ornithology and the Bibliographia Ornithologica Hungarica

\section{9}

97. ChERnEL I. (1889): A pusztai talpas-tyuk ez idei megjelenése hazánkban [2]. Vadász-Lap 10 (1): $3-5$.

98. Chernel I. (1889): Általános megjegyzések a szalonkahuzásról. Vadász-Lap 10 (11): 137.

99. CHERnEl I. (1889): Egy magyar „madárhegy” [1]. Sopron 19 (35): 1-2.

100. CHERNEL I. (1889): Egy magyar „madárhegy” [2]. Sopron 19 (36): 1-2.

101. CHERNEL I. (1889): Egy magyar „madárhegy” [3]. Sopron 19 (37): 1-2.

102. CHERNEL I. (1889): Egy magyar „madárhegy” [4]. Sopron 19 (38): 1-2.

103.CHERNEL I. (1889): Egy magyar madárhegy [1]. Vadász-Lap 10 (15): 193-194.

104. CHERNEL I. (1889): Egy magyar madárhegy [2]. Vadász-Lap 10 (16): 205-207.

105. CHERNEL I. (1889): Egy magyar madárhegy [3]. Vadász-Lap 10 (18): 235-236.

106. CHERnEl I. (1899): Kérelem a rózsaszínü seregély (Pastor roseur L.) megfigyelése ügyében. Vadász-Lap 10 (19): 247.

107. CHERNEL I. (1889): Hulló levelek. Vadász-Lap 10 (27): 351-353.

108. CHERNEL I. (1889): Csibegyilkos gyík. Sopron 19 (54): 2.

109. CHERnel I. (1889): Madártani kutatások a Fertő délkeleti részein és a „Hanyságban”. Sopron 19 (55): 2.

110. Chernel I. (1889): Kérelem a rózsaszínü seregély (Pastor roseus L.) megfigyelése ügyében. Természettudományi Közlöny 21 (239): 347.

111. CHERNEL I. (1889): Kérelem a rózsaszínü seregély (Pastor roseus L.) megfigyelése ügyében. Egyetértés 23 (177): 3. 
112. [CHERNEL I.] (1889). Ornithologisches [Wegen der Beobachtung des Rosenstares]. Oedenburger Zeitung 22 (146): 3.

113. CHERNEL I. (1889): Ornithologische Forschung an der Neusiedlersee und im „Hanyság”. Oedenburger Zeitung 22 (150): 1-2.

1890

114. CHERNEL I. (1890): Kőszegvidéki téli vadászatok. Vadász-Lap 11 (2): 23-24.

115. CHERNEL I. (1890): A madarak vándorlásához. Vadász-Lap 11 (15): 197-198.

116. CHERnEl I. (1890): Die Vogel-Sammlung im Schlosse Lockenhaus in Ungarn. Ornithologisches Jahrbuch 1 (3): 57-60.

117. CHERnEL I. (1890): Verhandlungen in Budapest bezüglich des II. ornithologischen Congresses. Ornithologisches Jahrbuch 1 (5): 101-103.

118. CHERNEL I. (1890): II. Internationaler ornithologischer Congress. Ornithologisches Jahrbuch 1 (9): 183-184.

119. TSCHUSI, V. \& CHERnEl I. (1890): Die ornithologische Literatur Oesterreich-Ungarns 1889 [1]. Ornithologisches Jahrbuch 1 (11): 217-224.

120. TSCHUSI, V. \& CHERnEl I. (1890): Die ornithologische Literatur Oesterreich-Ungarns 1889 [2]. Ornithologisches Jahrbuch 1 (12): 228-240.

1891

121. CHERNEL I. (1891): Interessantere Erscheinungen in der Vogelfauna Ungarns im Jahre 1890. Ornithologisches Jahrbuch 2 (4): 167-170.

122. TAuscher Gy. \& CHERnel I. (1891): A kék vércse. PETÉNYI J. S. hátrahagyott irataiból összeállítva. In: HERMAN O. (szerk.): PETÉNYI J. S. a magyar tudományos madártan megalapítója. 1799-1855. Életkép. K. M. Természettudományi Társulat, Budapest. pp. 45-80.

122a TAusCher Gy. \& CHERnEl I. (1891): Der Rotfussfalke. Cerchneis vespertina LinNÉ. Aus dem handschriftlichen Nachlasse des JOHANN SALOMON von PETÉNYI nach den vorgefundenen Notizen zusammengestellt von weil. Dr. Julius Tauscher und Stefan von Chernel. In: HeRMAN O. (szerk.): J. S. v. PETÉNYI der Begründer der wissenschaftlichen Ornithologie in Ungarn. Ein Lebensbild. Zweiter Internationaler Ornithologischer Congress, Budapest. pp 47-89.

123. CHERNEL I. (1891): A II. nemzetközi ornithológiai kongresszus előmunkálatai. Természettudományi Közlöny 23 (258): 81-82.

124. CHERnEl I. (1891): A világ legészakibb városában. - Uti naplómból. [1] Köszeg és Vidéke 11 (52): 1-3.

\section{2}

125. CHERnEl I. (1892): A világ legészakibb városában. - Uti naplómból. [2] Köszeg és Vidéke 12 (1): 1-2

126. CHERnel I. (1892): Madárvédelem. Köszeg és Vidéke 12 (5): 1-2.

127. CHERNEL I. (1892): Magyarosodás-közmivelödés. In: BERÉNYI P. (szerk.): Emlékkönyv a Soproni Irodalmi és Müvészeti Kör fennállásának 15-ik évfordulójára. Sopron. pp. 6466.

128. CHERnel I. (1892): Az újkori bálnavadászat. Természettudományi Közlöny 24 (275): 343-352. 
129. CHERNEL I. (1892): Az „Öreg Éger”. In: MTT TITKÁRSÁG (szerk.): Emlékkönyv a Királyi Magyar Természettudományi Társulat Félszázados Jubileumára. Budapest, K. M. Természettudományi Társulat, pp. 202-216.

130. Chernel I. (1892): Beobachtungen über das Brüten und den Zug des Phalaropus hyperboreus L. In: HeRMAN O. (szerk.) Föjelentés. Hauptbericht. - Második nemzetközi madártani Congressus. Zweiter internationaler Ornithologischer Congress Budapest 1891. II. Tudományos rész. Wissenschaftlicher Teil. Magyar Királyi Tudományegyetemi Könyvnyomda, Budapest. pp. 137-144.

131. CHERNEL I. (1892): Az északi víztaposó lile fészkelése és költözése. Természettudományi Közlöny 24 (272): 169-180.

132.CHERNEL I. (1892): A „Phalaropus hyperboreus” magyar elnevezése. Természettudományi Közlöny 24 (275): 389.

133. CHERNEL I. (1892): Az alvidéki szárnyas inségesek érdekében. Vadász-Lap 13 (22): 289290.

1893

134. Chernel I. (1893): Utazás Norvégia végvidékére. Szerzői kiadás, Budapest. 449 p.

135. CHERNEL I. (1893): A lábszánykózásról. Vasárnapi Ujság 40 (7): 110-112.

136. CHERNEL I. (1893): Mi ujság? Vasárnapi Ujság 40 (7): 117.

1894

137. CHERNEL I. (1894): Utazás Norvégia végvidékére [1]. Vadász-Lap 15 (19): 253-254.

138. CHERNEL I. (1894): Utazás Norvégia végvidékére [2]. Vadász-Lap 15 (21): 281-283.

139. CHERNEL I. (1894): Utazás Norvégia végvidékére [3]. Vadász-Lap 15 (22): 292-294.

140. CHERNEL I. (1894): Utazás Norvégia végvidékére [4]. Vadász-Lap 15 (24): 321-322.

141. Chernel I. (1894): Utazás Norvégia végvidékére [5]. Vadász-Lap 15 (25): 332-333.

142. CHERNEL I. (1894): Acanthis linaria. Ornithologische Monatsberichte 2 (4): 57-58.

143. CHERNEL I. (1894): Megjegyzések a mocsári poszáta (Acrocephalus palustris BECHST.) válfajáról - Bemerkungen über die Varietät des Sumpfrohrsängers. Aquila 1: 123-129.

144. CHERNEL I. (1894): A vörös fejü gébics (Lanius senator L.) és Cerchneis Naumanni FleSCH. Der Rothkopfwürger (Lanius senator L.) und der Rötelfalke (Cerchneis Naumanni FLESCH.). Aquila 1: 162-164.

145. CHERNEL I. (1894): A lábszánykózásról. Erdély 3 (1-2): 5-17.

\section{5}

146. CHERNEL I. (1895): Chernel Kálmán madárköltözési adatsorozatai és adatai. - Coloman Chernel v. Chernelháza's Daten und Serien über den Zug der Vögel. Aquila 2: 163-166.

147. CHERnEl I.: (1895): Fängehaltung des fliegenden Circus aeruginosus L. und Asio otus L.. Ornithologische Monatsberichte 3 (2): 26-27.

148. CHERNEL I.: (1895): [Seltenheiten am Velenczeer See erlegt.] Ornithologische Monatsberichte 3 (3): 44.

149. CHERNEL I.: (1895): Fängehaltung einiger fliegender Raubvögel. Ornithologische Monatsberichte 3 (8): 127.

150. CHERnEl I.: (1895): Berichtigung. Mittheilungen des ornithologischen Vereins in Wien 19 (7): 110.

151. Chernel I.: (1895): Kleine Mittheilungen - Erwiderung. Mittheilungen des ornithologischen Vereins in Wien 19 (9): 143-144. 
152. Chernel I.: (1895): A lábszánkó meghonosodása. Vasárnapi Ujság 42 (4): 58-60.

153. CHERNEL I.: (1895): A lábszánkó-versenyekről. Vasárnapi Ujság 42 (5): 66-69.

\section{6}

154. Chernel I. (1896): A költözködő madarak tavaszi megjelenése Köszegen. - Die Frühjahrs-Ankunft der Zugvögel in Köszeg (Güns). Aquila 3: 126-136.

155. CHERNEL I. (1896): Vörösfejű gébics (Lanius senator L.). - Der rothköpfige Würger (Lanius senator L.). Aquila 3: 229.

156. CHERnEl I. (1896): A gazdaságilag hasznos és kártékony madarakról. Köztelek 6 (31): 585-586.

157. CHERnEl I. (1896): A kurrogómadár (Locustella luscinioides SAV.) énekéröl. Természettudományi Közlöny 28 (324): 446-447.

158. CHERnEL I. (1896): Még egy kis kurrogás a kurrogó madárról. Természettudományi Közlöny 28 (325): 506.

159. CHERnEL I. (1896): Wie singt Locustella luscinioides SAV.? Ornithologische Monatsberichte 4 (10): 153-154.

160. Chernel I.: (1896): Az idei tél és a lábszánkózás. Vasárnapi Ujság 43 (8): 116-118.
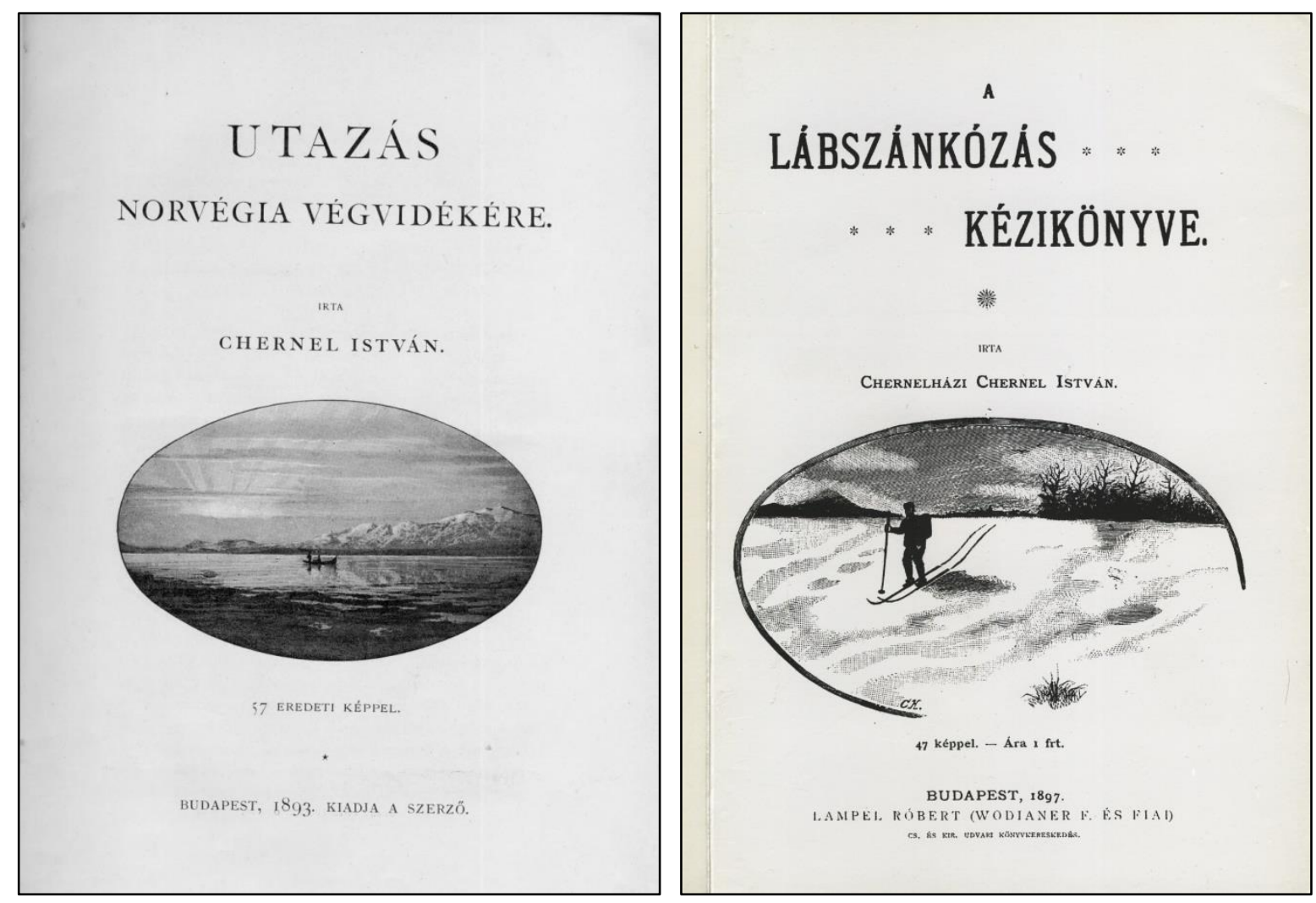

\section{3. ábra: Az 1892-es norvégiai utazás két könyv-eredménye: az Utazás Norvégia} végvidékére (1893) és a Lábszánkózás kézikönyve (1897)

Figure 3: Two book-results of the Norwegian tour in 1892: Expedition to the end region of Norway (1893) and The Handbook of Skiing (1897) 


\section{7}

161. CHERnel I. (1896): A lábszánkózás kézikönyve. Budapest, Lampel Róbert (Wodianer F. és fiai) cs. és kir. udvari könyvkereskedés, 78 p.

162. CHERNEL I. (1897): Megjegyzések az úgynevezett „eltévedt költözködő” madárfajokról. - Bemerkungen über die sogenannten „Irrgäste”. Aquila 4: 161-163.

163. CHERnEL I. (1897): A biológiai jegyek használatáról. - Über die Anwendung der biologischen Zeichen. Aquila 4: 260-261.

164. CHERnEL I. (1897): A Locustella luscinioides SAV. énekéröl. Természettudományi Közlöny 29 (334): 319-320.

165. CHERnEL I. (1897): Mein Schlusswort bezüglich des Rohrschwirl-Gesanges. Ornithologische Monatsberichte 5 (7): 105-106.

166. Chernel I. (1897): Az erdei szalonka vadászata. A Természet 1 (6): 9-11.

\section{8}

167. Chernel I. (1898): A fekete varjú (Corvus corone L.) Magyarország madárvilágában. Die Rabenkrähe (Corvus corone L.) in der Ornis Ungarns. Aquila 5: 289-292.

168. CHERnEL I. (1898): Die Zwergtrappe (Otis tetrax L.) in Ungarn. Ornithologische Monatsschrift 23 (3): 95-96.

169. Chernel I. (1898): A szalonka vadászata. A Természet 2 (4): 8-9.

170. CHERnEl I. (1898): A szalonkales. A Természet 2 (14): 8-9.

171. Chernel I. (1898): Madarak. In: SzIKLAY J. \& BorovszKY S. (szerk.): Magyarország vármegyéi és városai. Vasvármegye. „Apollo” Irodalmi és Nyomdai Részvénytársaság. Budapest, pp. 486-492.

172. [Chernel I.] Magyar ORnitológiai KÖZPONT (1898): Nomenclator avium Regni Hungariae. Magyarország madárfajainak elnevezései. Franklin-Társulat, Budapest. 80 p.

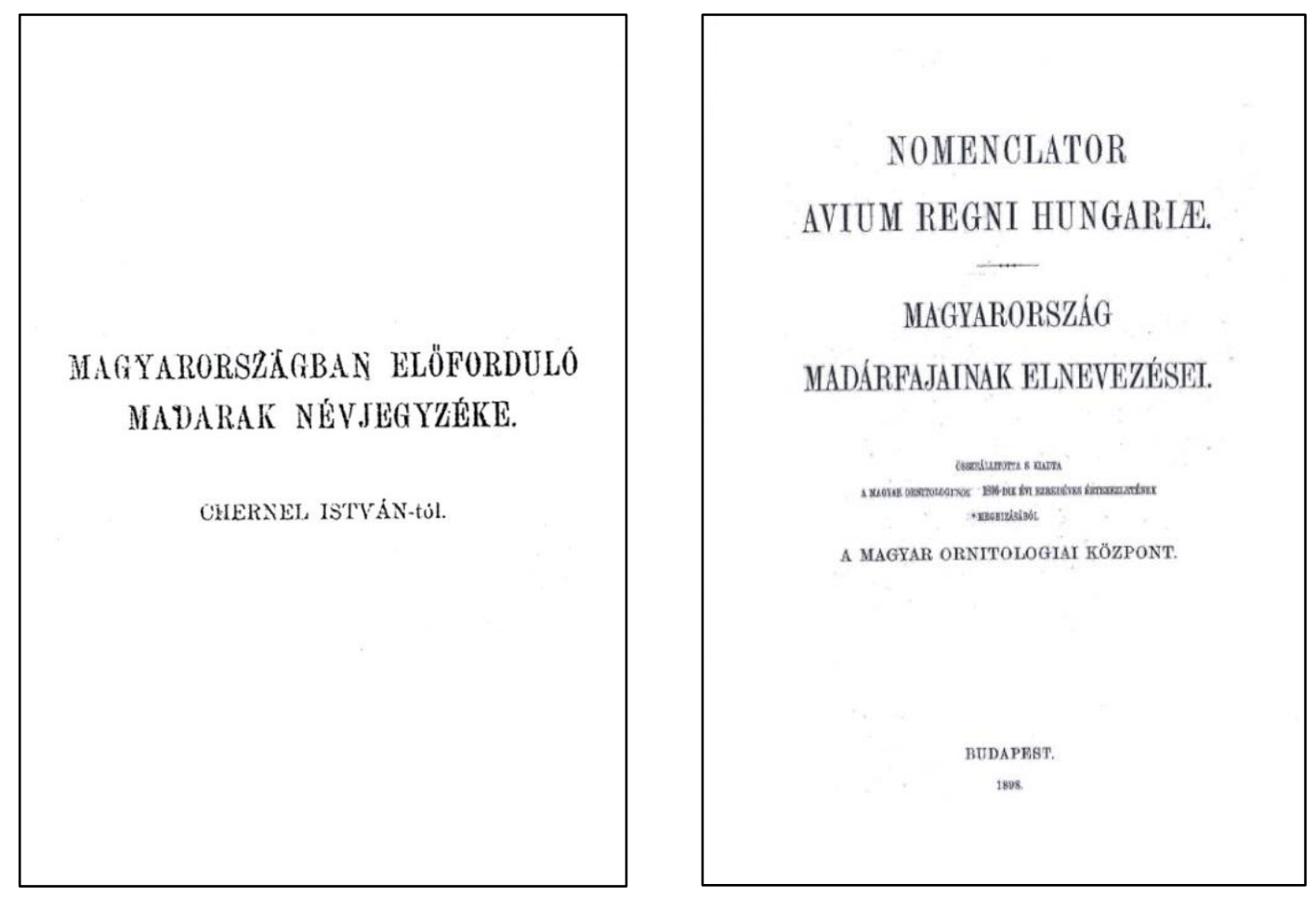

4. ábra: CHERNEL két magyar madárnévjegyzéke (1888 és1898)

Figure 4: CHERNEL's two check-lists of Hungarian birds (1888 and 1898) 


\section{9}

173. CHERNEL I. (1899): Magyarország madarai különös tekintettel gazdasági jelentőségökre. I-II. könyv. Magyar Ornithologiai Központ, Budapest. XXIV+187 p. + $\mathrm{XVI}+830 \mathrm{p}$.
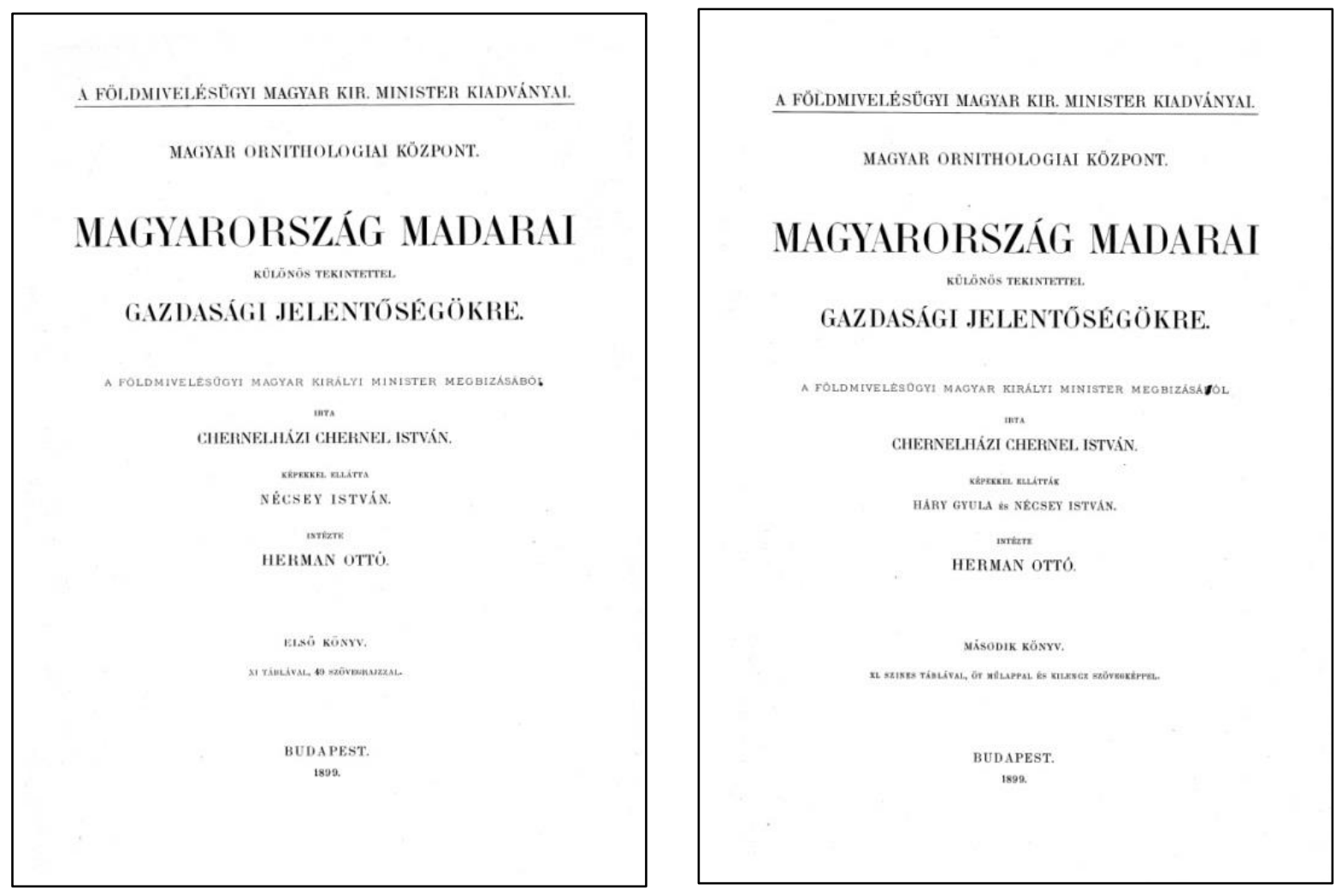

\section{5. ábra: CHERNEL ISTVÁN fő múve a Magyarország madarai különös tekintettel gazdasági jelentőségökre (1899)}

Figure 5: The mean work of ISTVÁN CHERNEL: Birds of Hungary with special regard to their economic importance (1899)

174. ChERnEl I. (1899): Czynk Ede 1851-1899. - Eduard Czynk 1851-1899. Aquila 6: 7081.

175. Chernel I. (1899): Megjegyzések dr. MAdARÁsz Gy.: „Újabb adatok Magyarország orniszához" cz. dolgozatára. - Bemerkungen über die Arbeit dr. J. v. MADARÁsz' „Further Contribution to the Hungarian Ornis". Aquila 6: 315-322.

176. Chernel I. (1899): Sterna cantiaca GM. Aquila 6: 325-326.

177. CHERnEL I. (1899): A madarak védelme - Vogelschutz. Aquila 6: 329-367.

178. Chernel I. (1899): Nemes kócsag - Edelreiher. Aquila 6: 368-373.

179. CHERnEl I. (1899): Válasz dr. Madarász Gyula urnak a „Természetrajzi füzetek” t. szerkesztőjéhez intézett nyilt levelére - Antwort auf den an den Redacteur der „Természetrajzi füzetek” gerichteten „Offenen Brief” des Herrn Dr. Julius von Madarász. Aquila 6: 401-402.

180. CHERNEL I. (1899): A madarak munkálkodásának jelentősége a természet háztartásában [1]. Vadász-Lap 20 (30): 395-399.

181. CHERNEL I. (1899): A madarak munkálkodásának jelentősége a természet háztartásában [2]. Vadász-Lap 20 (31): 407-410. 
182. CHERNEL I. (1899): A madarak munkájának értéke az ember gazdaságában [1]. VadászLap 20 (33): 440-442.

183. CHERNEL I. (1899): A madarak munkájának értéke az ember gazdaságában [2]. VadászLap 20 (34): 447-450.

184. CHERNEL I. (1899): A madarak hasznos és káros voltának fogalma. Természettudományi Közlöny 31 (363): 621-628.

185. Chernel I. (1899): Aegithalus és Remiza. A Természet 3 (7): 10.

186. Chernel I. (1899): A szalonka-hajtásról. A Természet 3 (14): 9-10.

\section{0}

187. CHERNEL I. (1900): A madarak hasznos és káros voltának fogalma [1]. Vadász-Lap 21 (24): 315-317.

188. CHERnEl I. (1900): A madarak hasznos és káros voltának fogalma [2]. Vadász-Lap 21 (25): 327-329.

189. Chernel I. (1900): A madarak védelme [1]. Köszeg és Vidéke 20 (5): 1-2.

190. CHERNEL I. (1900): A madarak védelme [2]. Köszeg és Vidéke 20 (6): 1-2.

191. Chernel I. (1900): A madarak védelme [3]. Köszeg és Vidéke 20 (7): 1-2.

192. CHERNEL I. (1900): A madarak védelme [4]. Köszeg és Vidéke 20 (8): 1-2.

193. ChERNEL I. (1900): A madarak védelme [5]. Köszeg és Vidéke 20 (9): 1-2.

194. CHERnEL I. (1900): A madarak védelme [6]. Köszeg és Vidéke 20 (10): 1-2.

195. Chernel I. (1900): A madarak védelme [7]. Köszeg és Vidéke 20 (11): 1-2.

196. Chernel I. (1900): A madarak védelme [8]. Köszeg és Vidéke 20 (12): 1-2.

197. CHERnEL I. (1900): A madarak védelme [9]. Köszeg és Vidéke 20 (13): 1-2.

198. CHERNEL I. (1900): A madarak védelme [10]. Köszeg és Vidéke 20 (14): 1-2.

199. Chernel I. (1900): Vogelschutz [1]. Günser Zeitung 19 (5): 1-2.

200. CHERNEL I. (1900): Vogelschutz [2]. Günser Zeitung 19 (6): 1-2.

201. ChERNEL I. (1900): Vogelschutz [3]. Günser Zeitung 19 (7): 1-2.

202. CHERnEL I. (1900): Vogelschutz [4]. Günser Zeitung 19 (8): 1-2.

203. Chernel I. (1900): Vogelschutz [5]. Günser Zeitung 19 (9): 1-2.

204. CHERnEl I. (1900): Vogelschutz [6]. Günser Zeitung 19 (10): 1-2.

205. ChERnEl I. (1900): Vogelschutz [7]. Günser Zeitung 19 (11): 1-2.

206. Chernel I. (1900): Vogelschutz [8]. Günser Zeitung 19 (12): 1-3.

207. Chernel I. (1900): Végső szavam a Remiza és Aegithalus ügyben. A Természet 3 (11): 10.

208. CHERNEL I. (1900): Az állatok és az ember. Állategészség 4 (3):62-64.

209. Chernel I. (1900): Fürj (Coturnix Bonn 1790) I. Köztelek 10 (31): 608-609.

210. Chernel I. (1900): Fürj (Coturnix Bonn 1790) II. Köztelek 10 (32): 636-637.

211. CHERNEL I. (1900): A rovarélet és madárélet viszonya I. Rovartani Lapok 7 (4): 67-70.

212. CHERNEL I. (1900): A rovarélet és madárélet viszonya II. Rovartani Lapok 7 (5): 93-96.

213. Chernel I. (1900): A tavasz hirdetöi: 1. A füsti fecske. Természettudományi Közlöny 32 (367): 153-159.

214. Chernel I. (1900): A tavasz hirdetői: 2. A darú. Természettudományi Közlöny 32 (367): 159-167.

215. CHERNEL I. (1900): A tavasz hirdetői: 3. A mezei pacsirta. Természettudományi Közlöny 32 (367): 168-171.

216. CHERnEL I. (1900): Rapport sur l'ouvrage intitulé. „, Les oiseaux de la Hongrie et leur importance économique”. Bureau Central Ornithologique Hongrois, Budapest. 22+X. p. 


\section{1}

217. CHERNEL I. (1901): A madarak hasznos és káros voltáról positiv alapon - Über Nützlichkeit und Schädlichkeit der Vögel auf positiver Grundlage. Aquila 8: 123-147.

218. ChERNEL I. (1901): Fászl István 1838-1900. - Stephan Fászl 1838-1900. Aquila 8: $173-181$.

219. CHERnEl I. (1901): A fenyőrigó (Turdus pilaris L.) fészkelése Magyarországon - Über Nisten der Wacholderdrossel (Turdus pilaris L.) in Ungarn. Aquila 8: 291-293.

220. CHERNEL I. (1901): Difformis csőrü madarak - Vögel mit difformen Schnäbeln. Aquila 8: 293-295.

221. CHERNEL I. (1901): A dankasirály gazdasági jelentőségéhez - Zur wirtschaftlichen Bedeutung der Lachmöwe. Aquila 8: 296.

1902

222. Chernel I./M. O. K. (1902): [A madarak megfogyatkozása.] Aquila 9: 227.

223. CHERnEl I. (1902): Áttelelési adatok (1901-1902) - Überwinterungsdaten (1901-1902). Aquila 9: 231.

224. CHERNEL I. (1902): Az állatok és különösen hasznos madaraink védelméröl. Köszeg, 10 p.

225. CHERnEl I. (1902): Vom Schutze der Thiere insbesondere vom Schutze der nützlichen Vögel. Landes-Thierschutzverein, Köszeg, Nyom. Feigl Frigyesnél. 14 p.

226. Chernel I. (1902): Az állatok és különösen hasznos madaraink védelméröl [1]. A Természet 6 (3): 5-7.

227. Chernel I. (1902): Az állatok és különösen hasznos madaraink védelméröl [2]. A Természet 6 (4): 7-9.

228. CHERNEL I. (1902): Az állatok és különösen hasznos madaraink védelméröl. Vasvármegye 35 (22): 1-5.

229. CHERnel I. (1902): Állatvédelem. Köszeg és Vidéke 22 (4): 2.

230. CHERnEl I. (1902): Thierschutz. Günser Anzeiger 29 (4): 1.

231. CHERnEL I. (1902): Az állatok és különösen hasznos madaraink védelméről [1]. Köszeg és Vidéke 22 (7):1-2.

232. CHERNEL I. (1902): Az állatok és különösen hasznos madaraink védelméröl [2]. Köszeg és Vidéke 22 (8):1-2.

233. CHERNEL I. (1902): Az állatok és különösen hasznos madaraink védelméröl. Nevelöoktatás (Pozsony) 3 (5): 71-75.

234. CHERnEl I. (1902): A fészkelöüregek kifüggesztése. Köszeg és Vidéke 22 (9): 2.

235. CHERNEL I. (1902): Vom Schütze der Thiere insbesondere vom Schütze der nützlichen Vögel. [1]. Günser Anzeiger 29 (7): 1-2.

236. CHERNEL I. (1902): Vom Schütze der Thiere insbesondere vom Schütze der nützlichen Vögel. [2]. Günser Anzeiger 29 (8): 1-2.

237. CHERnEl I. (1902): Vom Schütze der Thiere insbesondere vom Schütze der nützlichen Vögel. [3]. Günser Anzeiger 29 (9): 1-2.

238. CHERnEl I. (1902): Vom Schütze der Thiere insbesondere vom Schütze der nützlichen Vögel. [1]. Günser Zeitung 21 (7): 1-2.

239. CHERnEl I. (1902): Vom Schütze der Thiere insbesondere vom Schütze der nützlichen Vögel. [2]. Günser Zeitung 21 (8): 1-2.

240. CHERNEL I. (1902): Vom Schütze der Thiere insbesondere vom Schütze der nützlichen Vögel. [3]. Günser Zeitung 21 (9): 1-2.

241. ChERnEL I. (1902): Die Anbringung der Nistfästchen. Günser Zeitung 21 (10): 2. 
242. CHERNEL I. (1902): Tudnivalók a fészkelőládikák kifüggesztése dolgában. A Természet 6 (5): 9-10.

243. CHERnel I. (1902): Az állatok világa. 4. Madarak. Elsö kötet: Varjúszerü madarak. Brehm Alfréd ,Tierleben” címü nagy müvének magyarba átültetett kiadása. Ismereteink mai színvonalához és a hazai viszonyokhoz alkalmazta Chernel István. Légrády Testvérek, Budapest. 702 p.

\section{3}

244. CHERNEL I. (1903): A rövidujjú pacsirta [Alauda brachydactyla (LEISL.)], Magyarország madárvilágának új jelensége - Die kurzzehige Lerche [Alauda brachydactyla (LEISL.)], eine neue Erscheinung in der Ornis Ungarns. Aquila 10: 250-251.

245. CHERNEL I. (1903): A kucsmás billegető (Motacilla melanocephala LiCHT.) elfordulása a Királyhágón túl - Das Vorkommen der schwarzköpfigen Schafstelze (Motacilla melanocephala LichT.) jenseits des Királyhágó Gebirges. Aquila 10: 253.

246. CHERnEL I. (1903): Kesztyüben fészkelő nyaktekercs - Wendehals und Fäustling. Aquila 10: 254-255.

247. Chernel I. (1903): Bevezető. In: Kukuljevicz J. (szerk.): Az Országos Állatvédő Egyesület kőszegi fiókegyesületének 1. évkönyve az 1902. évröl. pp. 3-5.

248. CHERnel I. (1903): I. Történeti előzmények. In: KukulJeviCZ J. (szerk.): Az Országos Állatvédő Egyesület kőszegi fiókegyesületének 1. évkönyve az 1902. évről. pp. 6-9.

249. Chernel I. \& KuKulJevicz J. (1903): A kőszegi fiók-egyesület indítványa, madárvédelem tárgyában [az O.Á.V.E.-hez]. In: KuKULJEVICZ J. (szerk.): Az Országos Állatvédő Egyesület kőszegi fiókegyesületének 1. évkönyve az 1902. évröl. pp. 30-31.

250. [CHERNEL I.] (1903): Egyesületünk a II-ik országos mezőgazdasági kiállításon Pozsonyban. In: KuKulJEvicz J. (szerk.): Az Országos Állatvédő Egyesület kőszegi fiókegyesületének 1. évkönyve az 1902. évröl. pp. 41-44.

251. [CHERnEl I.] (1903): A fészkelő-házikókról. In: KuKULJEviCZ J. (szerk.): Az Országos Állatvédő Egyesület kőszegi fiókegyesületének 1. évkönyve az 1902. évről. pp. 45-49.

252. [CHERNEL I.] (1903): Tudnivalók a fészkelő-házikók kifüggesztése dolgában. In: KuKULJEviCz J. (szerk.): Az Országos Állatvédő Egyesület kőszegi fiókegyesületének 1. évkönyve az 1902. évröl. pp. 50-51.

253. [CHERNEL I.] (1903): Az etetőkről. In: KukULJEviCz J. (szerk.): Az Országos Állatvédő Egyesület kőszegi fiókegyesületének 1. évkönyve az 1902. évröl. pp. 52-58.

254. CHERnel I. (1903): Az állatok világa. 5. Madarak. Második kötet: Varjúszerü madarak (Folyt.), papagályszerü madarak, galambszerü madarak, tyúkszerü madarak, guvatszerü madarak, darúszerü madarak. Brehm Alfréd „Tierleben” cimü nagy müvének magyarba átültetett kiadása. Ismereteink mai színvonalához és a hazai viszonyokhoz alkalmazta Chernel István. Légrády Testvérek, Budapest. 678 p.

255. [CHERNEL I.] (1903): A kőszegi állatvédő egyesület évkönyvéről. [Bevezető]. Köszeg és Vidéke 23 (13): 2-3.

\section{4}

256. CHERnEl I./M.O.K. (1904): Vonulás és időjárás - Zug und Wetter. Aquila 11: 379-380.

257. CHERnel I. (1904): Az állatok világa. 6. Madarak. Harmadik kötet: Lileszerü madarak, úszószárnyúak, viharmadarak, vágómadarak, tüskésszárnyú madarak, nandúszerü madarak, szörös madarak, strucszerü madarak. Brehm Alfréd „Tierleben” címü nagy müvének magyarba átültetett kiadása. Ismereteink mai színvonalához és a hazai viszonyokhoz alkalmazta Chernel István. Légrády Testvérek, Budapest. 872 p. 


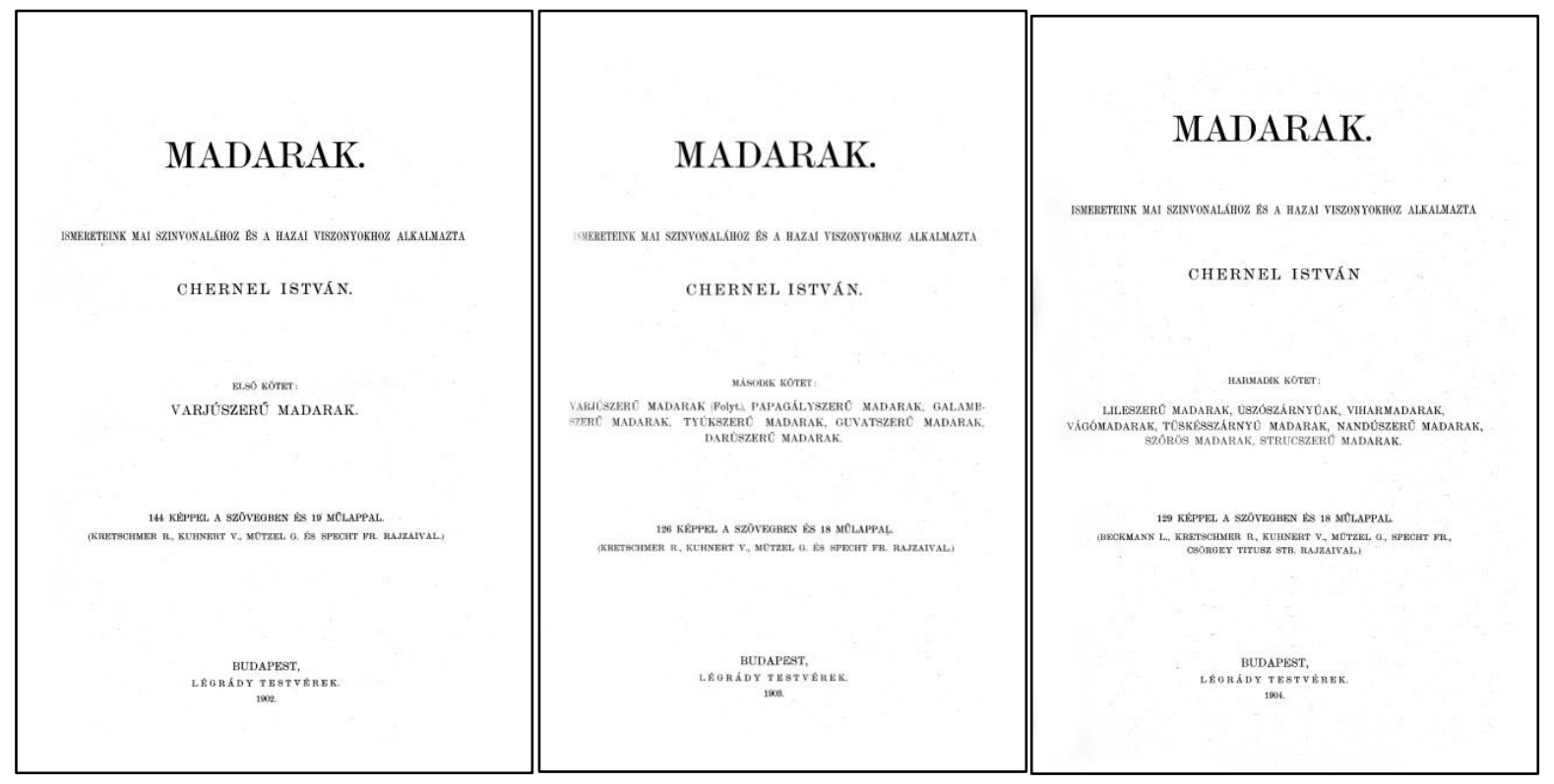

6. ábra: BREHM Tierleben c. sorozatából a 3 madaras kötetet CHERNEL ISTVÁN fordította magyarra és alkalmazta magyar viszonyokra

Figure 6: The three volumes of Birds of Brehm's „,Tierleben” series was translated to Hungarian and adapted to Hungarian circumstances by ISTVÁN CHERNEL

1905

258. CHERNEL I. (1905): A süket- és nyirfajd. Vadászat és Állatvilág 5 (10): 114-115.

259. [CHERnEl I.] (1905): Március 15 [Ünnepi beszéd]. Köszeg és Vidéke 25 (12): 2.

260. CHERnEl I. (1905): Die Feier des 15. März in Köszeg. [Festrede] Günser Anzeiger 32 (11): $1-2$

261. HenniCKe, C. R. (Hsg.). (1905): NAUMANN Naturgeschichte der Vögel Mitteleuropas. IXII. Band. Neu bearb. v. 36 Mitarbeitern. Közöttük CHERNEL I. Gera Untermhaus Lithographie, Druck und Verlag von Fr. Eugen Köhler.

1906

262. CHERnEl I. (1906): A Kőszegi Állatvédő Egyesület közgyülése. [Megnyitó beszéd] Állatvédelem 3 (6): 7.

263. Chernel I. \& Tolnay J. (1906): Egyesületi hirek - Köszegi egyesület. Állatvédelem 3 (7): 7.

1907

264. CHERnEl I. (1907): Adatok Magyarország madárfaunájához - Daten zur Vogelfauna Ungarns. Aquila 14: 179-187.

265. Chernel I. (1907): Aix galericulata (L.) Aquila 14: 337.

266. CHERnEl I. (1907): Az okszerü madárvédelem eszközei. Budapest. 45 p.

267. Chernel S. (1907): On variations in the colouring of Colymbus cristatus, C. griseigena, and C. nigricollis, observed at the Lake of Velencze in Hungary. In: SHARPE R. B., Hartert E. J. O. \& Bonhote J. L. (eds.): Proceedings of the Fourth International Ornithological Congress. London June 1905. Dulau \& Co., London. pp. 524-527. 
268. ChERnEl I. (1907): Sárladányi Schmidegg János gróf 1824-1907. Köszeg és Vidéke 27 (17): 2.

269. CHERnEL I. (1907): Berlepsch János báró Magyarországon és a Köszegi Állatvédő Egyesület közgyülése. Állatvédelem 4 (6): 5-7.

270. Chernel I. (1907): A macska és a madárvédelem. Állatvédelem 4 (11): 1-2.

\section{8}

271. CHERnEl I. (1908): A madárvédelemről és az e téren való teendőinkről [1]. Ellenzék (Kolozsvár) 29 (121): 1-2.

272. CHERnEl I. (1908): A madárvédelemről és az e téren való teendőinkről [2]. Ellenzék (Kolozsvár) 29 (122): 1-2.

273. CHERnEl I. (1908): A madárvédelemről és az e téren való teendőinkről. Kolozsvár, Ellenzék-Könyvnyomda, $15 \mathrm{p}$.

274. CHERNEL I. (1908): Madárvédelmi kirándulások. Állatvédelem 5 (7): 3-4.

1909

275. CHERNEL I. (1909): Uj etetőkészülék cinegék részére. Állatvédelem 6 (2): 16-17.

276. CHERNEL I. (1909): Adatok húsevő madaraink táplálkozásának kérdéséhez - Beiträge zur Nahrungsfrage unserer carnivoren Vogelwelt. Aquila 16: 145-155.

277. CHERNEL I. (1909): Rendellenes színezetü Emberiza citrinella L. - Farbenaberration bei Emberiza citrinella L. Aquila 16: 286-287

278. CHERnEl I. (1909): A kormos légykapó fészkelése Magyarországon - Das Nisten des schwarzgrauen Fliegenfängers (Muscicapa atricapilla L.) in Ungarn. Aquila 16: 293294.

279. CHernel I. (1909): Az állatvédő egyesületek feladatairól I. Pápai Hirlap 6 (45): 2-3.

280. Chernel I. (1909): Az állatvédő egyesületek feladatairól II. Pápai Hirlap 6 (46): 2-3.

281. Hajnal E. [ChERnEl I.] (1909): A fekete rigó [Levél a soproni Löver-bizottsághoz a fekete rigó ügyében.] Soproni Napló 13 (56): 1-3.

282. HAJNAL A. [CHERnEl I.] (1909): Die Amsel [Levél a soproni Löver-bizottsághoz a fekete rigó ügyében.]. Oedenburger Zeitung 42 (60): 9.

283. CHERnEl I. (1909): A madarak védelméröl Magyar Közmüvelödés [Székesfehérvár] 2 (1-4): 16-18.

1910

284. [CHERNEL I.] (1910): A madárvédelem kérdése az V-ik nemzetközi madártani kongresszuson. Allatvédelem 7 (2): 16-17.

285. CHERNEL I. (1910): Látogatásom Berlepsch János báró madárvédelmi telepein [1]. Állatvédelem 7 (9): 85-86.

286. CHERnEL I. (1910): Látogatásom Berlepsch János báró madárvédelmi telepein [2]. Állatvédelem 7 (10): 97-98.

\section{1}

287. CHERnEL S. (1911): Die gesellschaftliche Tätigkeit für praktischen Vogelschutz in Ungarn. In: ScHALOW H. (Hrsg.): Verhandlungen des V. Internationalen OrnithologenKongresses in Berlin. 30. Mai bis 4. Juni 1910. Deutsche Ornithologische Gesellschaft, Berlin. pp. 814-825. 
288. CHERNEL I. (1911): Társadalmunk tevékenysége a gyakorlati madárvédelem terén. In: MÁDAy I. \& CheRnel I.: Madárvédelmi törekvések Magyarországban. A társadalom közremüködése. Pátria, Budapest. pp. 51-77.

289. CHERNEL I. (1911): A torinoi nemzetközi állatvédő kongresszusról [I]. Állatvédelem 8 (11): 101.

290. Chernel I. (1911): A torinoi nemzetközi állatvédő kongresszusról II. Állatvédelem 8 (12): 109-110.

\section{2}

291. CHERNEl I. (1912): A torinoi nemzetközi állatvédő kongresszusról III. Állatvédelem 9 (1): 4-5.

292. [CHERnEL I.] (1912): A „Kőszegi Állatvédő Egyesület". [1911 évi müködéséről]. Allatvédelem 9 (4): 43-44.

293. CHERNEL I. (1912): Levél az olasz madárvásárról - Ein Brief vom italienischen Vogelmarkt. Aquila 19: 431-440.

294. CHERNEL I. (1912): Internationale Vorschriften, abzielend auf die Hintanhaltung der Vernichtung der nicht als Nahrung dienenden Seevögel gefordert. ['Indítvány a vízimadarak védelme érdekében'] II. Internationaler Jagdkongress 1910. I. pp. 186, 187

295. CHERnEl I. (1912): A „Kőszegi Állatvédő Egyesület” működéséről [1911]. Kőszeg és vidéke 32 (13): 2.

296. CHERNEL I. (1912): Indítvány a nemzetközi madárvédelem dolgában (francia nyelven) In: Congresso Internationale Societá Protettrici degli Animali. Zoofilo e umanitario. Torino (Italia), 12-15 Ottobre 1911. Torino, Tipografia L. Festa. pp. 91-101.

\section{3}

297. Chernel I. (1913): Chernel Mihály. Vasárnapi Ujság 60 (28): 552.

298. [CHERnel I.] (1913): A Kőszegi Állatvédő Egyesület [1912 évi működéséről]. Állatvédelem $10(8): 77$.

299. CHERnEl I. (1913): Chernel István jelentése a K. Á. E. 1912 évi müködéséröl [1]. Köszeg és vidéke 33 (29): 1-2.

300. ChERNEL I. (1913): Chernel István jelentése a K. Á. E. 1912 évi müködéséröl [2]. Köszeg és vidéke 33 (30): 1-2.

\section{4}

301. Chernel I. (1914): Kisebb közlemények - Bene-kecske. Magyar Nyelv 10 (7): 314316.

302. ChERnEl I. (1914): Népnyelv. Magyar Nyelv 10 (8): 377-382.

\section{5}

303. Chernel I. (1915): Herman Ottó. 1835 június 27. - 1914 deczember 27. - Otto Herman. Geb. am 27. Juni 1835, gest. am 27. Deczember 1914. Nachruf. Aquila 21: VII-XLVIII.

304. Chernel I. (1915): Komoly szó vadászainkhoz. (A törvényesen védett madarak pusztítása ellen). Vadász-Lap 36 (8): 87-90.

305. Chernel I. (1915): Telelő erdei szalonkák. Vadász-Lap 36 (6): 71.

306. CHERNEL I. (1915): A német katonák madárvédelme. Allatvédelem 12 (3-4): 15-16. 


\section{6}

307. CHERnEl I. (1916): Waisbecker Antal dr. 1835-1916. Köszeg és Vidéke 36 (15): 2.

\section{7}

308. [CHERnEL I.] (1917): Első Ferenc József Ö Felsége. [emlékezés] - Seine Majestät Franz Josef I. [Erinnerung] Aquila 23: 7, 430.

309. CHERNEL I. (1917): Uj korszak hajnalán - Anbruch eines neuen Zeitalters. Aquila 23: 812: 432-437.

310. CHERnel I. (1917): A csonttollú madár (Ampelis garrula L.) fészkeléséről hazánkban Über das Nisten des Seidenschwanzes (Ampelis garrula L.) in Ungarn. Aquila 23: 308 311, 502-505.

311. Chernel I. (1917): A darázsölyv (Pernis apivorus L.) fészkeléséről és hangjáról Horstbaum und Stimme des Wespenbussards (Pernis apivorus L.). Aquila 23: 312-314, 506.

312. CHERNEL I. (1917): Madártani adatok Chernel Miklós harctéri leveleiből Ornithologische Beiträge aus den Feldbriefen Nikolaus v. Chernel. Aquila 23: 331-332, 526-527.

313. CHERNEL I. (1917): A hajnalmadár (Tichodroma muraria L.) Zalamegyében. - Der Mauerläufer (Tichodroma muraria L.) im Komitate Zala. Aquila 23: 349, 549.

314. CHERnEL I. (1917): Áttelelő vonuló madarak. - Ueberwinternde Zugvögel. Aquila 23: 352-354, 552-555.

315. CHERNEL I. (1917): Az 1916. évi tavaszi madárvonulás Kőszegen - Der Frühjahrszug 1916 in Kőszeg. Aquila 23: 355-357, 555-557.

316. CHERNEL I. (1917): Adalék a hazai madárvonulás kísérleti megfigyeléséhez. - Beitrag zur experimentellen Beobachtung des heimischen Vogelzuges. Aquila 23: 363-364, 565-566.

317. CHERnel I. (1917): Irodalmi ismertetés - Ambrózy I. gr.: Háború és madárvédelem. Kérelem hölgyeinkhez. - Literaturbesprechung - Ambrózy St. Graf: Krieg und Vogelschutz. Eine Bitte an die Frauen. Aquila 23: 369-371, 569-571.

318. CHERnEL I. (1917): Wilamovitz-Moellendorff Wichard gróf 1873-1916. Necrologus Wichard Graf Wilamovitz-Moellendorff 1873-1916. Necrolog. Aquila 23: 388-389, 589-590.

319. CHERnEl I. (1917): Kocyán Antal 1834-1916. Necrologus - Anton Kocyán 1834-1916. Necrolog. Aquila 23: 391, 592-593.

320. Chernel I. (1917): Dr. Finsch Otto 1839-1917. Necrologus - Prof. Dr. Otto Finsch 1839-1917. Necrolog. Aquila 23: 392-395, 593-597.

321. ChERnEl I. (1917): Dresser Henri Eeles 1838-1915. Necrologus - Henry Eeles Dresser 1838-1915. Necrolog. Aquila 23: 396-397, 597-599.

322. CHERnEL I. (1917): Az erdei szalonka ivarának meghatározása. Vadász-Lap 38 (14): 160.

323. CHERnEL I. (1917): [Gólya tömeges kóborlása.] Vadász-Lap 38 (17): 207.

324. CHERnel I. (1917): Csaláncsúcs. Magyar Nyelv 13 (6): 201-203.

325. ChERnEl I. (1917): Chernel István újévi üdvözlete. Állatvédelem 14 (1): 4.

326. CHERnEL I. (1917): Madárvédelmi tapasztalatok. Állatvédelem 14 (9): 50-51.

327. Chernel I. (1917): A fecskék vonulása juliusban. Természettudományi Közlöny 49 (685-686): 784. 


\section{8}

328. CHERnEl I. (1918): Adatok Magyarország madárfaunájához. - Daten zur Vogelfauna Ungarns. Aquila 24: 7-14, 15-24.

329. CHERNEL I. (1918): Jegyzetek az őszi vonulásról a Balaton vidékéről. - Notizen über den Herbstzug aus der Gegend des Balaton-Sees. Aquila 24: 24-26, 27-29.

330. CHERnEl I. (1918): A havasi szürkebegy (Accentor collaris Scop.) előfordulása Zalavármegyében. - Das Vorkommen des Alpenflühvogels (Accentor collaris Scop.) im Komitate Zala. Aquila 24: 114-117, 118-121.

331. CHERnEl I. (1918): A füsti fecske (Hirundo rustica L.) és a fekete rigó (Turdus merula L.) fészeképítése az idei szárazságban. - Nestbau der Rauchschwalbe (Hirundo rustica L.) und der Amsel (Turdus merula L.) in der heurigen Trockenzeit. Aquila 24: 267., 280.

332. CHERnEL I. (1918): A kabasólyom (Falco subbuteo L.) fecskevadászata. - Die Schwalbenjagd des Lerchenfalks (Falco subbuteo L.). Aquila 24: 267., 281-282.

333. Chernel I. (1918): A túzok (Otis tarda L.) Vasmegyében. - Die Grosstrappe (Otis tarda L.) im Komitate Vas. Aquila 24: 268, 282.

334. Chernel I. (1918): Flavisztikus széncinege (Parus maior L.) - Flavismus an einer Kohlmeise (Parus maior L.). Aquila 24: 268, 282.

335. CHERnel I. (1918): A tőkés és nyílfarkú récék (Anas boschas L. et Dafila acuta L.) mezőgazdasági kártékonysága. - Von der landwirtschaftlichen Schädlichkeit der Stockund Spiessente (Anas boschas L. et Dafila acuta L.). Aquila 24: 268-269, 282-283.

336. CHERnEL I. (1918): Báró Szalay Imre 1846-1917. Necrologus - Emerich Freiherr von Szalay. 1846-1917. Nekrolog. Aquila 24: 300-301, 305-306.

337. Chernel I. (1918): Parlagi Béla 1856-1917. Necrologus - Béla Parlagi. 1856-1917. Nekrolog. Aquila 24: 303-305, 309-310.

338. [M. O. K (1918): Madárvonulási adatok Magyarországból. 1917-es évfolyam. Vogelzugsdaten aus Ungarn. Jahrgang 1917. Aquila 24: 241-261. - Chernel István (Kőszeg) adatai: 243-246 p.]

339. CHERnEl I. (1918): Freh Alfonz. 1832-1918. Köszeg és Vidéke 38 (27): 1-2.

340. [CHERNEL I.] (1918): Háború után. Állatvédelem 15 (9-10): 39.

341. Chernel I. (1918): Madarak és fák napja Németországban. Allatvédelem 15 (9-10): 40.

\section{9}

342. Chernel I. (1919): Kisérő szó az Aquila XXV-ik kötetéhez. - Geleitwort zum XXV-ten Band der „Aquila". Aquila 25: I-III; IV-VII.

343. Chernel I. (1919): A szibériai rigó (Turdus sibiricus Pall.), új jelenség Magyarország madárvilágában. - Die sibirische Drossel (Turdus sibiricus Pall.), eine neue Erscheinung in der Vogelfauna Ungarns. Aquila 25: 7-9; 10-13.

344. CHERnel I. (1919): Öszi megfigyelések a Balaton vidékéröl 1918-ban. Herbstbeobachtungen aus der Gegend vom Balatonsee im Jahre 1918. Aquila 25: 115126.

345. CHERnEL I. (1919): Middendorff Ernő. 1851-1916. Necrologus. - Ernst von Middendorff. 1851-1916. Necrolog. Aquila 25: 224-226, 226-228.

346. CHERNEl I. (1919): A magyar birodalom madarainak névjegyzéke. - Nomenclator Avium Regni Hungariae. Melléklet Aquila 25: 76 p. - Beilage zur Aquila 25.

347. CHERNEL I. (1919): [Erdei szalonkák a fán. Hozzászólás.] Vadász-Lap 40 (1): 12. 

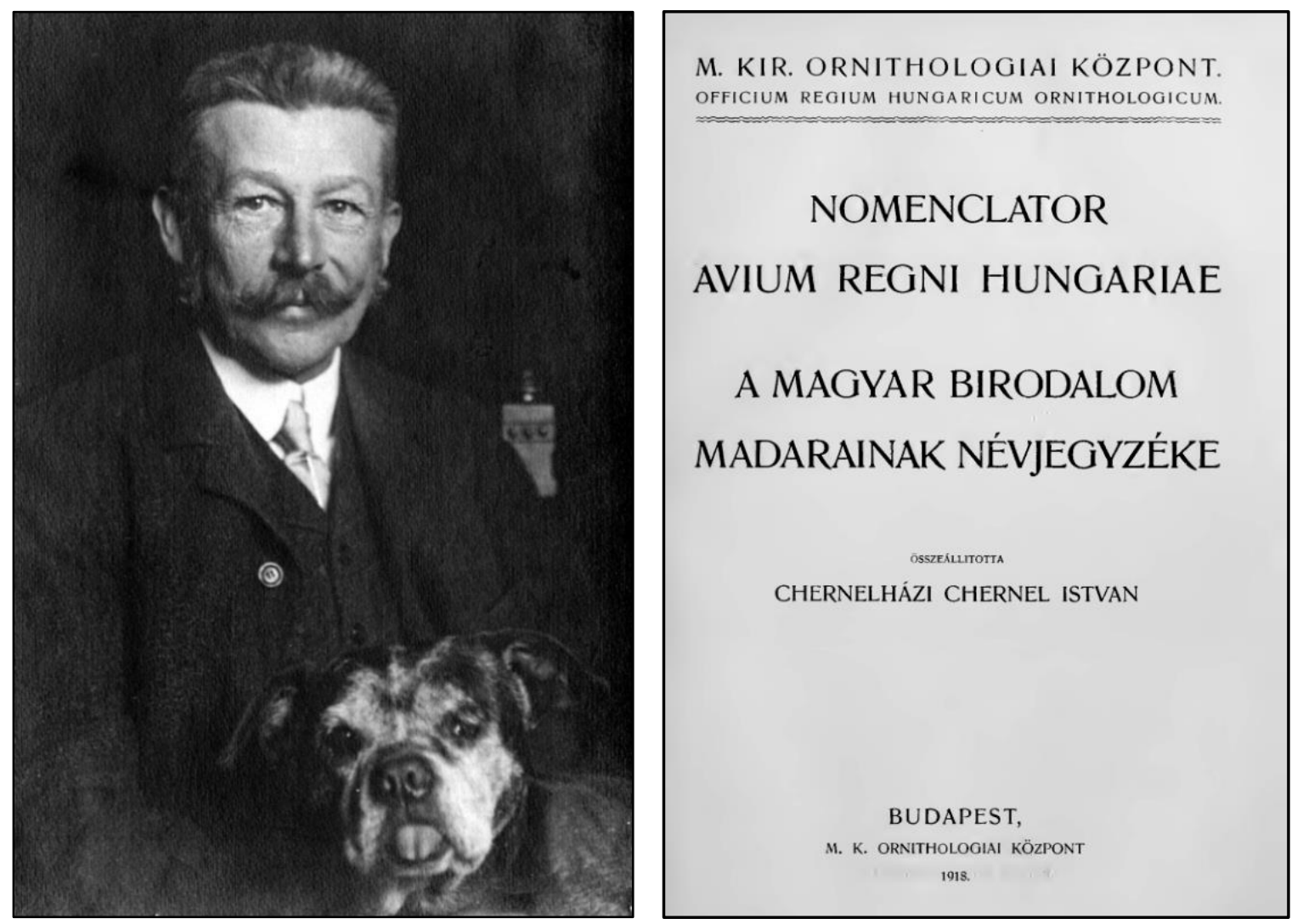

7. ábra: CHERNEL IsTVÁN a Madártani Intézet igazgatója és utolsó jelentős munkája a Magyar Birodalom madarainak névjegyzéke (1919)

(Savaria Múzeum, Természettudományi Osztály, Fotótár, KT216)

Figure 7: ISTVÁN CHERNEL Director of the Hungarian Ornithological Centre and his last important work: The check-list of birds of the Hungarian Empire (1919)

348. CHERNEL I. (1920): A madarak nemzetközi védelme. A párisi békekonferenciának szánt memorandum. - Internationaler Vogelschutz. Für die Friedensverhandlungen in Paris bestimmte Denkschrift. Aquila 26: 7-15, 16-25.

349. CHERnEL I. (1920): Öszi megfigyelések a Balaton vidékéről 1919-ben. Herbstbeobachtungen aus der Gegend vom Balatonsee im Jahre 1919. Aquila 26: 41-45.

350. Chernel I. (1920): Bezerédj Ignácz levele Sibrik Antal győri alispánhoz. - Brief des Ignatz Bezerédj an Anton Sibrik. Aquila 26: 106, 128.

351. Chernel I. (1920): A nagy kócsag (Egretta alba L.) állománya a Fertő taván. - Der Bestand der Silberreiher (Egretta alba L.) am Fertö-See. Aquila 26: 106-107, 128.

352. Chernel I. (1920): Pásztormadár (Pastor roseus L.) Vasmegyében. - Ein Rosenstar (Pastor roseus L.) im Komitate Vas. Aquila 26: 110, 132.

353. CHERnEL I. (1920): A vörösnyakú lúd újabb előfordulása Magyarországon. - Neueres Vorkommen der Rothalsgans in Ungarn. Aquila 26: 110, 132.

354. Chernel I. (1920): A rozsdástorkú pipis (Anthus cervinus Pall.) Vasmegyében. - Der rotkehlige Pieper (Anthus cervinus Pall.) im Komitate Vas. Aquila 26: 110, 132.

355. Chernel I. (1920): Gólyák (Ciconia alba L.) decemberben. - Störche (Ciconia alba L.) im Dezember. Aquila 26: 115., 137.

356. CHERnEl I. (1919): Madármegfigyelő állomások. - Vogelwarten. Aquila 26: 147-149, 149-151. 
357. [SCHENK J. (1920): Madárvonulási adatok Magyarországból. II. (1919-es) évfolyam Vogelzugsdaten aus Ungarn. II. Jahrgang (1919). Aquila 26: 46-75. - Chernel István (Kőszeg) adatai: 48-55 p.]

1921

358. CHERnEL I. (1921): Törvény- vagy rendelettervezet honi madaraink védelméről. Entwurf eine Verordnung oder eines Gesetzes betreffend den Schutz der heimischen Vögel. Aquila 27: 7-11, 11-15.

359. CHERnEl I. (1921): Adatok a Balaton és Velencei tó madárfaunájához. - Beiträge zur Vogelfauna des Balaton und Velenczeer See. Aquila 27: 244-245, 264-266.

360. CHERNEL I. (1921): Hegyi billegetök (Motacilla boarula L.) az etetőn. - Gebirgsstelzen (Motacilla boarula L.) am Futterplatz. Aquila 27: 263, 281.

361. [SCHENK J. (1921): Madárvonulási adatok Magyarországból. III. (1920-as) évfolyam Vogelzugsdaten aus Ungarn. III. Jahrgang (1920). Aquila 27: 39-55. - Chernel István (Kőszeg) adatai: 40-42 p.]

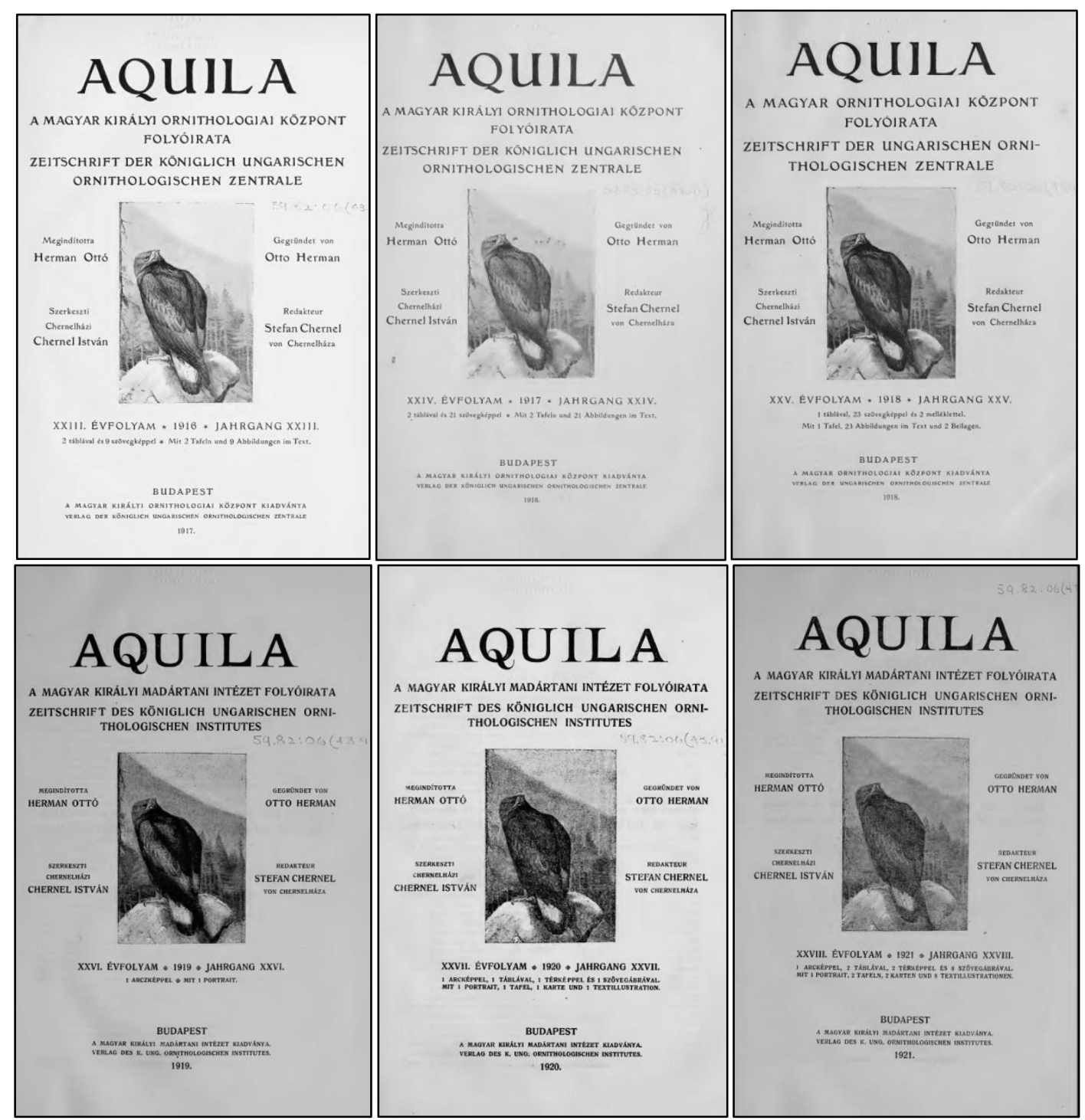

8. ábra: Az Aquila évkönyv hat kötete, amit CHERNEL ISTVÁN szerkesztett

Figure 8: The six volumes of yearbook of institute Aquila edited by ISTVÁN CHERNEL 
362. Chernel I. (1922): A trianoni béke és Magyarország madárvilága. - Der Friede von Trianon und die Vogelwelt Ungarns. Aquila 28: 41-47.

363. CHERNEL I. (1922): Jegyzetek a Balaton mellékéről 1921 őszén. - Herbstnotizen (1921) vom Balaton-See. Aquila 28: 127-130.

364. CHERnEl I. (1922): A szajkó (Garrulus glandarius L.) károsságához. - Zur Schädlichkeit des Eichelhähers (Garrulus glandarius L.). Aquila 28: 166-167, 200-202.

365. Chernel I. (1922): Ugartyúk (Oedicnemus scolopax Gm.) Somogymegyében. - Triel (Oedicnemus scolopax Gm.) im Komitate Somogy. Aquila 28: 177, 210-211.

366. CHERnel I. (1922): Kanalasgémek (Platalea leucorodia L.) Vasmegyében. Löffelreiher (Platalea leucorodia L.) im Komitate Vas. Aquila 28: 177, 210-211.

367. Chernel I. (1922): Siketfajd (Tetrao urogallus L.) a sikságon. - Auerhuhn (Tetrao urogallus L.) in der Ebene. Aquila 28: 177-178, 211.

368. Chernel I. (1922): Sarki buvár (Colymbus arcticus L.) Köszegen. - Polarseetaucher (Colymbus arcticus L.) in Köszeg. Aquila 28: 186, 216.

Az első, ScHERMANN-féle irodalomjegyzékben (SCHERMANN, 1922) 29. tétel alatt szereplö, 1886-ban állítólag megjelent két közlés nem található a Köszeg és Vidéke 6. évfolyama 48. és 49. számában. Ennek hibás voltát alátámasztja, hogy nem szerepel sem VÉRTESI PÉTERNÉ (VÉRTESI 1981), sem ugyanő később, - lánykori nevén: SRAGNER MÁRTA - publikált (SRAGNER, 2004) az OSZK honlapján, a Magyar Elektronikus Könyvtárban elérhető közlésében.

Nem CHERNEL cikk, csak adataira hivatkozik, vagy megfigyelését mutatja be

TSCHUSI V., LAZARINI, L. \& CHERNEL, I. (1888): Die ornithologische Literatur OesterreichUngarns 1887. Mittheilungen des Ornithologischen Vereins in Wien 12 (6-8): 111-115.. [SCHERMANN, 1922 No 54; VÉRTESI 1981 No 40.] - mit Beiträgen...CHERNEL, de CHERNEL nem nevesített szerzőtárs.

CHERnEl I. (1896): Oedicnemus indicus. Ornithologische Monatsberichte 4 (11): 187. [SCHERMANN, 1922 No. 114] CHERNEL megfigyelését mutatja be, de nem CHERNEL cikk!

\section{ISMÉTELT KÖZLÉSEK E BIBLIOGRÁFIA TÉTELSORSZÁMAI SZERINT}

1. CHERnEl I. (1885): Öngyilkosság és halálos ítélet az állat illetőleg a madárvilágból. I. Köszeg és Vidéke 5 (20): 1-3.

40. CHERNEL I. (1885): Öngyilkosság és halálos ítélet az állat-, illetőleg, a madárvilágban I. Hon 1 (8): 2.

55. CHERNEL I. (1886): A madarak életkora [1]. Köszeg és Vidéke 6 (25): 1-2.

56. CHERnEl I. (1886): A madarak életkora [2]. Köszeg és Vidéke 6 (26): 1-2.

57. CHERNEL I. (1886): A madarak életkora. Pozsonyvidéki Lapok 14 (100): 2-3.

62. Chernel I. (1887): Madártani megfigyelések Pozsony vidékén 1885-ben. A Pozsonyi Természettudományi és Orvosi Egylet Közleményei 1884-1886, Pressburg. pp.41-65.

63. CHERNEL I. (1887): Madártani megfigyelések Pozsony vidékén 1885-ben. Vadász-Lap 8 (17): 219-220. (részben) 
64. CHERNEL I. (1887): A velenczei tó-vidék életéből. Vadász-Lap 8 (29): 374-377.

76. CHERNEL I. (1888): A velenczei tó-vidék életéből. Vadász-és Verseny-Lap 32 (2): 29-31.

71. CHERNEL I. (1887): A honi madártan történetéböl. A madártan fejödése a XVIII-ik század végéig. Természettudományi Közlöny 19 (218): 415-418.

67. CHERNEL I. (1887): A honi madártan történetéböl. I. - A madártan fejődése a XVIII. század végéig. Vadász-Lap 8 (36): 477-478.

72. CHERnEl I. (1887): A honi madártan történetéből. II. E század elejétől a Kir. Magy. Természettudományi Társulat megalapításáig. Természettudományi Közlöny 19 (219): 456-460.

77. CHERNel I. (1888): A honi madártan történetéböl. II. E század elejétöl a Kir. Magy. Természettudományi Társulat megalapításáig. Vadász-Lap 9 (1): 4-6.

75. Chernel I. (1888): A honi madártan történetéből. III. A madártan kifejlődése a Kir. Magy. Természettudományi Társulat alapításától napjainkig, azaz 1841-től 1888-ig. Természettudományi Közlöny 20 (221): 55-62.

78. CHERNEL I. (1888): A honi madártan történetéböl. III. A madártan kifejlődése a Kir. Magy. Természettudományi Társulat megalapításától napjainkig, azaz 1841-től 1888-ig Vadász-Lap 9 (9): $115-116$.

79. Chernel I. (1888): A honi madártan történetéből. III [2]: A madártan kifejlődése a Kir. Magy. Természettudományi Társulat megalapításától napjainkig, azaz 1841-től 1888-ig. Vadász-Lap 9 (10): $126-128$.

91. Chernel I. (1888): A pusztai talpas-tyúk ez idei megjelenése hazánkban. Természettudományi Közlöny 20 (232): 449-457.

82. CHERNEL I. (1888): A pusztai talpas-tyuk ezidei megjelenése hazánkban. Vadász-Lap 9 (36): 473-474.

97. CHERNEL I. (1889): A pusztai talpas-tyuk ez idei megjelenése hazánkban [2]. Vadász-Lap 10 (1): 3-5.

99. CHERnEl I. (1889): Egy magyar „madárhegy” [1]. Sopron 19 (35): 1-2.

100. CHERNEL I. (1889): Egy magyar „madárhegy” [2]. Sopron 19 (36): 1-2.

101. CHERNEL I. (1889): Egy magyar „madárhegy” [3]. Sopron 19 (37): 1-2.

102. CHERNEL I. (1889): Egy magyar „madárhegy” [4]. Sopron 19 (38): 1-2.

103. CHERNEL I. (1889): Egy magyar madárhegy [1]. Vadász-Lap 10 (15): 193-194.

104. CHERNEL I. (1889): Egy magyar madárhegy [2]. Vadász-Lap 10 (16): 205-207.

105. CHERNEL I. (1889): Egy magyar madárhegy [3]. Vadász-Lap 10 (18): 235-236.

134. Chernel I. (1893): Utazás Norvégia végvidékére. Szerzői kiadás, Budapest. 449 p.

Részletek a könyvböl

124. CHERNEL I. (1891): A világ legészakibb városában - Uti naplómból [1] Köszeg és Vidéke 11(52): 1-3.

125. CHERNEL I. (1892): A világ legészakibb városában. - Uti naplómból [2] Köszeg és Vidéke 12 (1): 1-2.

137. CHERNEL I. (1894): Utazás Norvégia végvidékére [1]. Vadász-Lap 15 (19): 253-254.

138. CHERNEL I. (1894): Utazás Norvégia végvidékére [2]. Vadász-Lap 15 (21): 281-283.

139. CHERNEL I. (1894): Utazás Norvégia végvidékére [3]. Vadász-Lap 15 (22): 292-294.

140. CHERNEL I. (1894): Utazás Norvégia végvidékére [4]. Vadász-Lap 15 (24): 321-322.

141. CHERNEL I. (1894): Utazás Norvégia végvidékére [5]. Vadász-Lap 15 (25): 332-333.

173. CHERNEL I. (1899): Magyarország madarai különös tekintettel gazdasági jelentőségökre. I-II. könyv. Magyar Ornithologiai Központ, Budapest. XXIV+187 p. + XVI+830 p. 
Részletek a könyvből, könyvfejezetekböl

A madarak hasznos és káros voltának fogalma

184. CHERnEL I. (1899): A madarak hasznos és káros voltának fogalma. Természettudományi Közlöny 31 (363): 621-628.

187. CHERNEL I. (1900): A madarak hasznos és káros voltának fogalma [1]. Vadász-Lap 21 (24): 315-317.

188. CHERNEL I. (1900): A madarak hasznos és káros voltának fogalma [2]. Vadász-Lap 21 (25): 327-329.

A madarak munkálkodásának jelentösége a természet háztartásában

180. CHERNEL I. (1899): A madarak munkálkodásának jelentősége a természet háztartásában [1]. VadászLap 20 (30): 395-399.

181. CHERNEL I. (1899): A madarak munkálkodásának jelentősége a természet háztartásában [2]. VadászLap 20 (31): 407-410.

211. CHERNEL I. (1900): A rovarélet és madárélet viszonya I. Rovartani Lapok 7 (4): 67-70.

212. CHERNEL I. (1900): A rovarélet és madárélet viszonya II. Rovartani Lapok 7 (5): 93-96.

A madarak munkájának értéke az ember gazdaságában

182. CHERNEL I. (1899): A madarak munkájának értéke az ember gazdaságában [1]. Vadász-Lap 20 (33): 440-442.

183. CHERNEL I. (1899): A madarak munkájának értéke az ember gazdaságában [2]. Vadász-Lap 20 (34): 447-450.

208. CHERNEL I. (1900): Az állatok és az ember. Allategészség 4 (3):62-64.

A madarak védelme

189. CHERNEL I. (1900): A madarak védelme [1]. Köszeg és Vidéke 20 (5): 1-2.

190. CHERNEL I. (1900): A madarak védelme [2]. Köszeg és Vidéke 20 (6): 1-2.

191. CHERNEL I. (1900): A madarak védelme [3]. Köszeg és Vidéke 20 (7): 1-2.

192. CHERnEl I. (1900): A madarak védelme [4]. Köszeg és Vidéke 20 (8): 1-2.

193. CHERnEl I. (1900): A madarak védelme [5]. Köszeg és Vidéke 20 (9): 1-2.

194. CHERnEl I. (1900): A madarak védelme [6]. Köszeg és Vidéke 20 (10): 1-2.

195. CHERNEL I. (1900): A madarak védelme [7]. Köszeg és Vidéke 20 (11): 1-2.

196. CHERnEl I. (1900): A madarak védelme [8]. Köszeg és Vidéke 20 (12): 1-2.

197. CHERnEl I. (1900): A madarak védelme [9]. Köszeg és Vidéke 20 (13): 1-2.

198. CHERNEL I. (1900): A madarak védelme [10]. Köszeg és Vidéke 20 (14): 1-2.

199. CHERNEL I. (1900): Vogelschutz [1]. Günser Zeitung 19 (5): 1-2.

200. CHERNEL I. (1900): Vogelschutz [2]. Günser Zeitung 19 (6): 1-2.

201. CHERNEL I. (1900): Vogelschutz [3]. Günser Zeitung 19 (7): 1-2.

202. CHERNEL I. (1900): Vogelschutz [4]. Günser Zeitung 19 (8): 1-2.

203. CHERNEL I. (1900): Vogelschutz [5]. Günser Zeitung 19 (9): 1-2.

204. CHERNEL I. (1900): Vogelschutz [6]. Günser Zeitung 19 (10): 1-2.

205. CHERNEL I. (1900): Vogelschutz [7]. Günser Zeitung 19 (11): 1-2.

206. CHERNEL I. (1900): Vogelschutz [8]. Günser Zeitung 19 (12): 1-3.

Egyes fajok bemutatása

178. CHERNEL I. (1899): Nemes kócsag - Edelreiher. Aquila 6: 368-373.

209. Chernel I. (1900): Fürj (Coturnix Bonn 1790) I. Köztelek 10 (31): 608-609.

210. CHeRnel I. (1900): Fürj (Coturnix Bonn 1790) II. Köztelek 10 (32): 636-637.

213. Chernel I. (1900): A tavasz hirdetői: 1. A füsti fecske. Természettudományi Közlöny 32 (367): 153159.

214. CHeRnel I. (1900): A tavasz hirdetői: 2. A darú. Természettudományi Közlöny 32 (367): 159-167.

215. Chernel I. (1900): A tavasz hirdetői: 3. A mezei pacsirta. Természettudományi Közlöny 32 (367): $168-171$.

226. Chernel I. (1902): Az állatok és különösen hasznos madaraink védelméröl [1]. A Természet 6 (3): 5-7.

227. Chernel I. (1902): Az állatok és különösen hasznos madaraink védelméröl [2]. A Természet 6 (4): 7-9.

228. CHERNEL I. (1902): Az állatok és különösen hasznos madaraink védelméröl. Vasvármegye 35 (22): 15. 
231. CHERNEL I. (1902): Az állatok és különösen hasznos madaraink védelméről [1]. Köszeg és Vidéke 22 (7):1-2.

232. CHERNEL I. (1902): Az állatok és különösen hasznos madaraink védelméröl [2]. Köszeg és Vidéke 22 (8):1-2.

233. CHERNEL I. (1902): Az állatok és különösen hasznos madaraink védelméröl. Nevelö-oktatás (Pozsony) $3(5): 71-75$.

235. CHERNEL I. (1902): Vom Schütze der Thiere insbesondere vom Schütze der nützlichen Vögel. [1]. Günser Anzeiger 29 (7): 1-2.

236. Chernel I. (1902): Vom Schütze der Thiere insbesondere vom Schütze der nützlichen Vögel. [2]. Günser Anzeiger 29 (8): 1-2.

237. CHERnEl I. (1902): Vom Schütze der Thiere insbesondere vom Schütze der nützlichen Vögel. [3]. Günser Anzeiger 29 (9): 1-2.

238. Chernel I. (1902): Vom Schütze der Thiere insbesondere vom Schütze der nützlichen Vögel. [1]. Günser Zeitung 21 (7): 1-2.

239. CHERNEL I. (1902): Vom Schütze der Thiere insbesondere vom Schütze der nützlichen Vögel. [2]. Günser Zeitung 21 (8): 1-2.

240. Chernel I. (1902): Vom Schütze der Thiere insbesondere vom Schütze der nützlichen Vögel. [3]. Günser Zeitung 21 (9): 1-2.

229. CHERNEL I. (1902): Állatvédelem. KöSzeg és Vidéke 22 (4): 2.

230. CHERNEL I. (1902): Thierschutz. Günser Anzeiger 29 (4): 1.

\section{SZAKMAI VITÁK}

Chernel István és MADARász Gyula vitája a nádi tücsökmadár (Locustella luscinioides) énekéről

\section{Vita itthon a Természettudományi Közlönyben}

MADARÁSZ GY. (1896): A kurrogó madár Locustella luscinioides Sav. Természettudományi Közlöny 28 (322): 311.

157. CHERNEL I. (1896): A kurrogómadár (Locustella luscinioides SAV.) énekéröl. Természettudományi Közlöny 28 (324): 446-447.

MADARÁSz Gy. (1896): A kurrogómadár (Locustella luscinioides Sav.) énekéröl. Természettudományi Közlöny 28 (324): 447-448.

SzIKLA G. (1896): A Locustella luscinioides Sav. énekéröl. Természettudományi Közlöny 28 (325): 505-506.

158. CHERNEL I. (1896): Még egy kis kurrogás a kurrogó madárról. Természettudományi Közlöny 28 (325): 506.

HeRMAN O. (1896): A Locustella luscinioides Sav. Természettudományi Közlöny 28 (326): 552-554.

MADARÁsz Gy. (1896): A nádi fülemüle énekéröl. Természettudományi Közlöny 28 (326): 554-555.

164. CHERnEL I. (1897): A Locustella luscinioides SAV. énekéröl. Természettudományi Közlöny 29 (334): 319-320.

\section{Vita az Ornithologische Monatsberichte hasábjain}

159. CHERNEL I. (1896): Wie singt Locustella luscinioides SAV.? Ornithologische Monatsberichte 4 (10): 153-154.

MADARÁSz Gy. (1897): Über den Gesang von Locustella luscinioides. Ornithologische Monatsberichte 5 (5): 69-73.

165. CHERnEL I. (1897): Mein Schlusswort bezüglich des Rohrschwirl-Gesanges. Ornithologische Monatsberichte 5 (7): 105-106.

MADARÁSZ GY. (1897): Zum Nachtigall-Rohrsänger-Streit. Ornithologische Monatsberichte 5 (9): 69-73. 


\section{ChERNEL IsTVÁN és MADARÁSz GYULA vitája Magyarország orniszáról}

MADARÁSZ GY. (1899): Újabb adatok Magyarország orniszához. - Further contribution to the Hungarian Ornis. Természetrajzi Füzetek 22: 344-360.

175. Chernel I. (1899): Megjegyzések dr. MAdARÁsz Gy.: „Újabb adatok Magyarország orniszához” cz. dolgozatára. - Bemerkungen über die Arbeit dr. J. v. MADARÁsz' „Further Contribution to the Hungarian Ornis". Aquila 6: 315-322.

MADARÁsz Gy. (1899): Nyilt levél a szerkesztőhöz. - Offener Brief an den Redacteur. Természetrajzi Füzetek 22: 495-499.

179. Chernel I. (1899): Válasz dr. Madarász Gyula urnak a „Természetrajzi füzetek” t. szerkesztőjéhez intézett nyilt levelére - Antwort auf den an den Redacteur der „Természetrajzi füzetek” gerichteten „Offenen Brief” des Herrn Dr. Julius von Madarász. Aquila 6: 401-402.

MADARÁsz Gy. (1899): Aegithalus és Remiza. A Természet 3 (5): 10-11.

185. Chernel I. (1899): Aegithalus és Remiza. A Természet 3 (7): 10.

MADARÁsz Gy. (1899): Aegithalus és Remiza. A Természet 4 (1): 10.

207. Chernel I. (1900): Végső szavam a Remiza és Aegithalus ügyben. A Természet 3 (11): 10.

\section{CHERNEL ISTVÁN és KenESSEY LÁSZLÓ vitája}

KENESSEY L. (1895): Ornithologisches aus Ungarn vom Jahre 1894. Mittheilungen des ornithologischen Vereins in Wien ,Die Schwalbe” 19 (5): 69-70.

150. CHERNEL I.: (1895): Berichtigung. Mittheilungen des ornithologischen Vereins in Wien „Die Schwalbe” 19 (7): 110.

KenESSEY, L. (1895): Entgegnung. Mittheilungen des ornithologischen Vereins in Wien Die Schwalbe 19 (8): 127.

151. ChERnEl I.: (1895): Kleine Mittheilungen - Erwiderung. Mittheilungen des ornithologischen Vereins in Wien „Die Schwalbe” 19 (9): 143-144.

\section{Polémia a siketfajdról és a nyírfajdról}

TÜRNBÖK G. (1905): Néhány szó a fö- és őzvadagancs javitása érdekében. Vadászat és Állatvilág 5 (9): 90.

259. CHERnEl I. (1905): A süket- és nyirfajd. Vadászat és Allatvilág 5 (10): 114-115.

\section{IRODALOMJEGYZÉK}

FARAGÓ S. (2014): Chernel István naplója nyugat-európai utazásáról. 1891. augusztus 7-30. Magyar Apróvad Közlemények 12: 1-32.

FARAGÓ, S. (2015): Lélekkel teljesitett hivatás. Chernelházi Chernel István naplója 19141922. I-II kötet. Nyugat-magyarországi Egyetem Kiadó, Sopron. 493+609 p.

FARAGÓ S. (2016): Chernelházi Chernel István emléktáblájának avatása Sopronban. Soproni Szemle 70 (1): 74-75.

FARAGÓ S. (2017): Emlékezés chernelházi Chernel Istvánra születésének 150. évfordulója alkalmából. Aquila 122-123: 7-29. 
FARAGÓ S. \& MAJTHÉNYI L. (2015a): Másfél évszázada született a madarak vadászó, Európahírü tudósa. Nimród Vadászújság 103 (6): 54-59.

FARAGÓ S. \& MAJTHÉNYI L. (2015b): Másfél évszázada született CHERNEL IsTVÁN, a madarak Európa-hírü tudósa. Életünk 53 (12): 3-14.

FARAGÓ S. (2019): Biografien osteuropäischer Ornithologen (34): István (Stefan) von CHERNEL zu Chernelháza (1865-1922) - Einer der Begründer der modernen ungarischen Ornithologie, zweiter Direktor des Ungarischen Ornithologischen Institutes. Ornithologische Mitteilungen 71 (3-4): 87-94.

SCHERMANN Sz. (1922): Chernel István munkáinak chronologikus jegyzéke. Chronologisches - Verzeichnis der Publikationen Stefan von Chernels. Aquila 28: 33-40.

SRAGNER M. (2004): Chernel István (1865-1922) - A madártan kutatója, a sísport magyarországi meghonosítója müveinek és szakcikkeinek bibliográfiája. Budapest, Neumann Kht. - URL: http://mek.oszk.hu/05100/05144

VÉRTESI P.-NÉ [SRAGNER M.] (1981): Chernel István-ornitológus. Vasi Életrajzi Bibliográfiák 5. Berzsenyi Dániel Megyei Könyvtár, Szombathely. 64 p.

\section{KÖSZÖNETNYILVÁNÍTÁS}

Köszön a Soproni Egyetem Központi Könyvtára és Levéltára munkatársainak, - különösen TOMPA MÓNIKA könyvtári és levéltári föigazgatónak és TOMPA ZsOLTNÉ könyvtári informatikus egyetemi fötanácsosnak -, hogy a hiányzó tételek könyvtárközi beszerzésével lehetővé tették a CHERNEL Bibliográfia teljessé tételét.

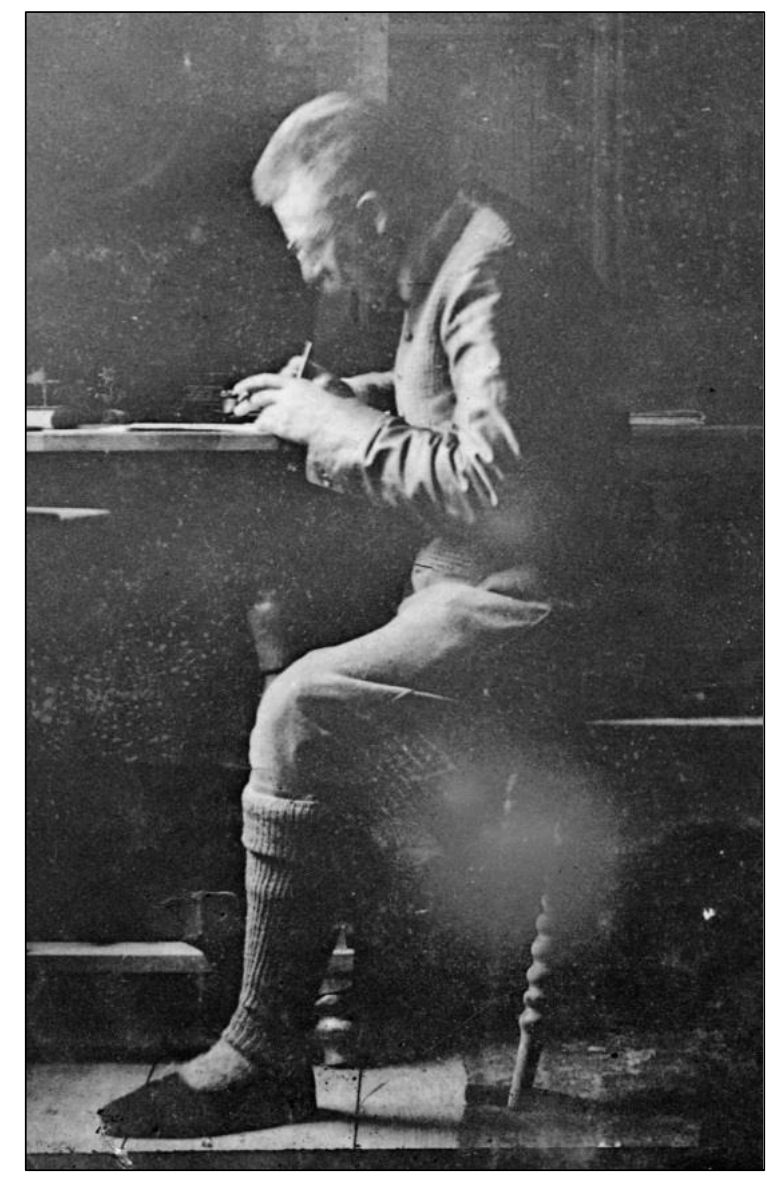

9. ábra: CHERNEL ISTVÁN íróasztalánál, munka közben, (Savaria Múzeum, Természettudományi Osztály, Fotótár, KT 215) Figure 9: ISTVÁN CHERNEL at his desk while working 